Article

\title{
Effect of Metal Content on Ethanol Decomposition over Ni-Co Catalysts Supported on La-Ce Oxides
}

\author{
Harold R. Vergara ${ }^{1}$, Maria H. Brijaldo ${ }^{1,2}$, José J. Martinez ${ }^{1} \oplus$, Hugo A. Rojas ${ }^{1}$, José Pedraza ${ }^{2}$, \\ Fabio B. Passos ${ }^{3}$, , Luiz Pereira da Costa ${ }^{4}$, Daniela Gonzalez-Vera ${ }^{5}$ and Paula Osorio-Vargas $5,6, *$ \\ 1 Grupo de Catálisis (GC-UPTC), Universidad Pedagógica y Tecnológica de Colombia UPTC, Avenida Central \\ del Norte, Vía Paipa, Tunja 150001, Colombia; harold.vergara@uptc.edu.co (H.R.V.); \\ maria.brijaldo@uptc.edu.co (M.H.B.); jose.martinez@uptc.edu.co (J.J.M.); hugo.rojas@uptc.edu.co (H.A.R.) \\ 2 Grupo de Investigación en Gestión Administrativa y Empresarial Sostenible (GIGAS), Universidad \\ Pedagógica y Tecnológica de Colombia UPTC, Avenida Central del Norte, Vía Paipa, Tunja 150001, \\ Colombia; jose.pedraza@uptc.edu.co \\ 3 Laboratório de Reatores, Cinética e Catalise (RECAT), Departamento de Engenharia Química e de Petróleo, \\ Universidade Federal Fluminense, Niterói 24210-240, Brazil; fabiopassos@id.uff.br \\ 4 Graduate Program in Science and Technology for Amazon Resources (PPGCTRA)-Institute of Exact Sciences \\ and Technology (ICET/UFAM), ItcRua: Nossa Senhora do Rosario, 3863, Tiradentes, \\ Itacoatiara-Amazonas 69103-208, Brazil; lupeco7@hotmail.com \\ 5 Grupo de Investigación en Fotocatálisis y Estado Sólido (GIFES), Escuela de Química, Universidad \\ Tecnológica de Pereira, 660003 Pereira, Colombia; danielagonzalez06@utp.edu.co \\ 6 Laboratory of Thermal and Catalytic Processes (LPTC), Department of Chemical Engineering, \\ University of Bío-Bío, Concepción 4081112, Chile \\ * Correspondence: posorio@ubiobio.cl; Tel.: +564-311-1161
}

Received: 16 December 2019; Accepted: 3 February 2020; Published: 7 February 2020

check for updates

\begin{abstract}
The search for catalysts with features that can improve coke resistance and decrease byproduct formation is a current goal in $\mathrm{H}_{2}$ production from renewable sources. In this work, the effect of the presence of $\mathrm{Ni}$ nanoparticles over $\mathrm{Co} / \mathrm{La}-\mathrm{Ce}$ oxides on the ethanol decomposition reaction was studied. Catalysts were synthetized using as precursor a $\mathrm{La}_{0.8} \mathrm{Ce}_{0.2} \mathrm{Ni}_{\mathrm{x}} \mathrm{Co}_{1-\mathrm{x}} \mathrm{O}_{3}$ perovskite-type material to ensure a low segregation of phases and a high dispersion of metals. After reduction at $873 \mathrm{~K}$, the perovskite structure was destroyed, and metal Co-Ni particles were supported over a lanthanum-cerium oxide. The materials were characterized by different techniques before and after reaction. Solids exhibited metal particle sizes between 5 and $15 \mathrm{~nm}$ demonstrating the advantages of the preparation method to obtain Ni-Co alloys. Although the results of adsorption of ethanol followed by diffuse reflectance infrared fourier transformed spectroscopy (DRIFTS) showed acetate species strongly adsorbed on the catalyst's surface, the material $\left(\mathrm{Ni}_{0.7} \mathrm{Co}_{0.3} / \mathrm{La}_{0.8} \mathrm{Ce}_{0.2}\right)$ with the lowest particle size was the most stable system leading to the lowest amount of carbon deposits during ethanol decomposition. This catalyst showed the better performance, with a higher ethanol conversion $(98.4 \%)$ and hydrogen selectivity $(75 \%)$. All catalysts exhibited carbonaceous deposits, which were an ordered and disordered carbon phase mixture.
\end{abstract}

Keywords: bimetallic catalysts; Ni-Co; ethanol decomposition; perovskite precursor; supports of La-Ce oxides

\section{Introduction}

Currently, fossil fuels such as coal, oil, and natural gas are the conventional energy sources. Their continuous use can negatively affect the environment. For this reason, sustainable and renewable energy sources are necessary in order to reduce pollutant emissions and preserve the environment. 
Within these renewable energies, $\mathrm{H}_{2}$ seems to be a promising fuel which can be obtained from several byproducts originated from biomass conversion. For instance, ethanol, which can be produced by simultaneous saccharification and fermentation (SSF) [1], exhibits interesting features as a $\mathrm{H}_{2}$ source. Several chemical processes such as ethanol steam reforming (ESR), partial oxidation (POE), oxidative steam reforming (OSPE), and catalytic ethanol decomposition (ED) have been evaluated for $\mathrm{H}_{2}$ production. In particular, ED (Equation (1)) shows interesting characteristics since it is an endothermic reaction $\left(\Delta \mathrm{H}^{\circ}=49.6 \mathrm{~kJ} \mathrm{~mol}^{-1}\right)$ requiring less energy than the more widely studied ESR process $\left(\Delta \mathrm{H}^{\circ}=173.5 \mathrm{~kJ} \mathrm{~mol}^{-1}\right)$. However, as is the case with ESR, ED exhibits some drawbacks related to the existence of simultaneous reactions such as the Boudouard reaction (Equation (2)) and methane decomposition (Equation (3)), which could lead to catalyst deactivation by deposition of carbonaceous species [2].

$$
\begin{aligned}
\mathrm{CH}_{3} \mathrm{CH}_{2} \mathrm{OH} & \rightarrow \mathrm{CH}_{4}+\mathrm{CO}+\mathrm{H}_{2} \quad \Delta \mathrm{H}^{\circ}=\mathrm{kJ} \mathrm{mol}^{-1} \\
2 \mathrm{CO} & \rightarrow \mathrm{CO}_{2}+\mathrm{C} \quad \Delta \mathrm{H}^{\circ}=-172.6 \mathrm{~kJ} \mathrm{~mol}^{-1} \\
\mathrm{CH}_{4} & \rightarrow \mathrm{C}+2 \mathrm{H}_{2} \quad \Delta \mathrm{H}^{\circ}=74.9 \mathrm{~kJ} \mathrm{~mol}^{-1}
\end{aligned}
$$

At low temperatures, where reaction (2) is more important, the catalyst can be deactivated through the formation of amorphous carbon deposits covering the metal particles. When the reaction is carried out at high temperatures $\left(>600{ }^{\circ} \mathrm{C}\right)$, reaction (3) becomes important, participating as well in the formation of carbonaceous species. However, on $\mathrm{Ni}$ and Co particles, this deposited carbon nucleates the growth of carbon filaments do not lead to total catalyst deactivation, since these filaments can push off the metal particles from the support leaving the metal accessible to reactants and exhibiting a minor deactivating effect [3].

Therefore, one of the main drawbacks to overcome so that this kind of process can be considered a viable route for the clean production of $\mathrm{H}_{2}$ is related to the stability and resistance of the catalysts toward coke formation. This can be achieved by a catalyst tailored to reduce coke formation or favor its rapid conversion into gaseous byproducts. In the literature, several approaches have been proposed to achieve this goal: (i) use of a support which can help carbon removal, (ii) particle ensemble size control, and (iii) addition of a second metal in order to improve modifications in catalytic performance. Regarding this last approach, a recent study highlighted a marked improvement in catalyst stability when $1 \%$ Rh was added to $10 \% \mathrm{Ni} / \mathrm{Al}_{2} \mathrm{O}_{3}$ promoted with $\mathrm{La}_{2} \mathrm{O}_{3}$ and $\mathrm{CeO}_{2}$ [4]. In that case, deposition of carbon decreased by 560 times compared with the Ni catalyst. In contrast, controlling the ensemble size seeks to inhibit carbon formation since a critical ensemble size is necessary for its formation. ESR measurements performed by Rostrup-Nielsen [5] showed that this reaction needs ensembles of 3 or 4 atoms, whereas carbon formation requires 6 or 7 atoms. Hence, particle size can influence carbon nucleation. In the search to control the particle ensemble size, catalysts using layered double hydroxide $(\mathrm{LDH})$ and perovskite-type structures $\left(\mathrm{ABO}_{3}\right)$ as precursors have been investigated [6-10]. Reduction of LDH or perovskite-type structures leads to high dispersion on corresponding oxides. Manukyan et al. [7] obtained a Ni/ $\mathrm{Al}_{2} \mathrm{O}_{3}$ system from the reduction of a Ni-Al hydrotalcite-type material. Those authors evaluated the deactivation of $\mathrm{Ni}-\mathrm{Al}_{2} \mathrm{O}_{3}-\mathrm{LDH}$ and $\mathrm{Ni} / \mathrm{Al}_{2} \mathrm{O}_{3}$ catalysts in the ethanol decomposition reaction. The XPS results showed that the amount of carbon increased up to $48 \%$ after $100 \mathrm{~h}$ time on stream (TOS) and $2 \mathrm{~h}$ TOS for $\mathrm{Ni}-\mathrm{Al}_{2} \mathrm{O}_{3}-\mathrm{LDH}$ and $\mathrm{Ni} / \mathrm{Al}_{2} \mathrm{O}_{3}$, respectively, which was related to the load and size of the metal particles. The $80 \% \mathrm{Ni}_{-} \mathrm{Al}_{2} \mathrm{O}_{3}-\mathrm{LDH}$ catalyst exhibited nickel with small particle sizes having diameters around $3-5 \mathrm{~nm}$, whereas Ni particles on the $10 \% \mathrm{Ni} / \mathrm{Al}_{2} \mathrm{O}_{3}$ catalyst were around 7-15 nm. Gallego et al. [9] also obtained Ni nanoparticles (15 nm, mean diameter) highly dispersed on $\mathrm{La}_{2} \mathrm{O}_{3}$ when prepared by reduction of $\mathrm{LaNiO}_{3}$ perovskite. This catalyst was very active for the ethanol decomposition reaction to $\mathrm{H}_{2}$ production and carbon nanotubes. In general, an important number of studies based on supported metal catalysts ( $\mathrm{Ni}, \mathrm{Co}$, and $\mathrm{Fe}$ ) on different supports such as $\mathrm{La}_{2} \mathrm{O}_{3}, \mathrm{CeZrO}_{2}, \mathrm{MgO}, \mathrm{Al}_{2} \mathrm{O}_{3}, \mathrm{CeO}_{2}$, and graphite for $\mathrm{H}_{2}$ production by ethanol decomposition have been published [7-9,11-20]. In fact, some studies have been focusing on both $\mathrm{H}_{2}$ production 
and carbon nanotube (CNT) production instead of the removal of carbonaceous deposits on metallic particles [9,15-19].

Taking into account the above-mentioned strategies to improve catalyst activity and stability by decreasing carbon deposition, the goal of this research was to study the effect of a second metal presence (Ni) in $\mathrm{Co} / \mathrm{La}-\mathrm{Ce}$ oxide catalysts prepared from a perovskite-type $\mathrm{La}_{0.8} \mathrm{Ce}_{0.2} \mathrm{Ni}_{\mathrm{x}} \mathrm{Co}_{1-\mathrm{x}} \mathrm{O}_{3}$ precursor for the ethanol decomposition reaction. This preparation method may favor the formation of small metal particles. The active phase was modified with different $\mathrm{Ni}$ and $\mathrm{Co}$ amounts to study a possible synergistic effect between both metals, since each one has already exhibited a good performance individually on catalytic ethanol decomposition. Their oxophilic nature favors $\mathrm{O}-\mathrm{H}$ bond activation of ethanol [21]. Mixed La-Ce oxides were selected in the search for supports that increase catalyst stability, as both oxides have been used with excellent results in this type of reaction $[9,20,22]$. The lattice oxygen of $\mathrm{CeO}_{2}$ can react with adsorbed hydrocarbons on surface, producing synthesis gas and thus preventing the formation of carbon species from hydrocarbon decomposition reactions $\left(\mathrm{C}_{\mathrm{m}} \mathrm{H}_{\mathrm{m}} \rightarrow\right.$ $\mathrm{nC}+\mathrm{m} / 2 \mathrm{H}_{2}$ ) [20]. The effect of $\mathrm{Co}$ and Ni metal amounts on the physico-chemical catalyst properties, $\mathrm{H}_{2}$ production, and carbon depositions in the reaction of ethanol decomposition at a temperature range from $303 \mathrm{~K}$ to $973 \mathrm{~K}$ was evaluated.

\section{Materials and Methods}

\subsection{Catalyst Synthesis and Characterization}

Perovskites were prepared by the polymeric precursor method or Pechini method [23] that allows, in general, to obtain a homogeneous organometallic polymer where metal is located in the polymer's main chain. The cation salts $\left(\mathrm{La}\left(\mathrm{NO}_{3}\right)_{3} \cdot 6 \mathrm{H}_{2} \mathrm{O}, \mathrm{Ce}\left(\mathrm{NO}_{3}\right)_{3} \cdot 6 \mathrm{H}_{2} \mathrm{O}, \mathrm{NiCl}_{2} \cdot 6 \mathrm{H}_{2} \mathrm{O}\right.$, and $\left.\mathrm{CoCl}_{2} \cdot 6 \mathrm{H}_{2} \mathrm{O}\right)$ were mixed with the suitable amounts to obtain the $\mathrm{La}_{0.8} \mathrm{Ce}_{0.2} \mathrm{Ni}_{\mathrm{x}} \mathrm{Co}_{1-\mathrm{x}} \mathrm{O}_{3}(\mathrm{x}=0,0.1,0.4$, and 0.7) perovskites and then were added to a solution of citric acid (CA) and ethylene glycol (EG). The ratio molar of CA:EG:metal ions was of 6:3:1. The prepared solution was slowly heated to $353 \mathrm{~K}$ under constant stirring until gel formation. The resulting resin containing cations was further heated to $623 \mathrm{~K}$ for $3 \mathrm{~h}$ yielding a fine powder. This material was calcined at $773 \mathrm{~K}$ for $1 \mathrm{~h}$ and then at $973 \mathrm{~K}$ for $6 \mathrm{~h}$ $\left(5 \mathrm{~K} \mathrm{~min}^{-1}\right)$. Perovskite precursors were subsequently transformed to metal catalysts supported on oxides of $\mathrm{Ce}$ and $\mathrm{La}$, by reduction under $\mathrm{H}_{2}$ flow $\left(30 \mathrm{~mL} \mathrm{~min}^{-1}\right)$ at $873 \mathrm{~K}$ for $2 \mathrm{~h}$. After this, the samples were passivated, using an $\mathrm{O}_{2}(1 \%) / \mathrm{He}$ mixture for $0.5 \mathrm{~h}$ at $\mathrm{N}_{2}$ liquid temperature to carry out some characterization techniques.

The textural properties were obtained from $\mathrm{N}_{2}$ physisorption analysis at $77 \mathrm{~K}$ in an ASAP 2020 Micromeritics instrument (Micromeritics Instrument Corp., Norcross, GA, USA). The passivated catalysts were treated at $593 \mathrm{~K}$ for $12 \mathrm{~h}$ and outgassed at $393 \mathrm{~K}$ for $2 \mathrm{~h}$ under $\mathrm{N}_{2}$ flow. The surface area values were determined from the Brunauer-Emmett-Teller model (BET model) and the pore-size distributions were calculated from the $\mathrm{N}_{2}$ adsorption branch using the Barrett, Joyner, and Halenda method (BJH method). X-ray diffraction (XRD) analyses were performed on a Rigaku Miniflex II instrument (Rigaku Corporation, Tokyo, Japan) with $\mathrm{Cu}$ K radiation $(\mathrm{k} \alpha=0.154 \mathrm{~nm})$ using a $0.05^{\circ}$ step size. $\mathrm{H}_{2}$ chemisorption was studied to determine metallic dispersion assuming an adsorption stoichiometry of $\mathrm{H} / \mathrm{M}=1$. A typical protocol was followed, the solids dried at $473 \mathrm{~K}$ for $1 \mathrm{~h}\left(30 \mathrm{~mL} \mathrm{~min}{ }^{-1}\right)$ were posteriorly reduced under in situ $\mathrm{H}_{2}\left(30 \mathrm{~mL} \mathrm{~min}^{-1}\right)$ for $2 \mathrm{~h}$ at $873 \mathrm{~K}$ in a Micromeritics ASAP 2020 instrument (Micromeritics Instrument Corp.). Afterward, the surface was cleaned under He flow at the same temperature for $1 \mathrm{~h}$ at $873 \mathrm{~K}$. Then, the systems were brought to room temperature and total hydrogen isotherms were acquired. To determine the total acidity, the solids previously purged were submitted to adsorption of ammonia saturated at $383 \mathrm{~K}$ in $10 \% \mathrm{NH}_{3} / \mathrm{He}$ flow $\left(30 \mathrm{~mL} \mathrm{~min}^{-1}\right)$. Temperature-programmed desorption was performed using a heating rate of $10 \mathrm{~K} \mathrm{~min}^{-1}$, from room temperature until reaching $1173 \mathrm{~K}$.

Temperature-programmed reduction (TPR) analysis was performed in a Micromeritics Autochem 2920 analyzer (Micromeritics Instrument Corp.). The catalysts (100 mg) were dried under He flow 
at $573 \mathrm{~K}$ for $0.5 \mathrm{~h}$ and the TPR profiles were obtained by heating the samples under a $10 \% \mathrm{H}_{2} / \mathrm{Ar}$

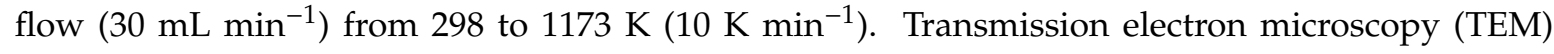
micrographs were obtained on a Jeol JEM 2100 HTP apparatus (Jeol Ltd., Tokyo, Japan) operating at $200 \mathrm{kV}$. The samples were suspended in isopropanol and ultrasonicated for $0.5 \mathrm{~h}$. A drop of the suspension was dropped onto carbon-coated copper grids, allowing the solvent to evaporate at $353 \mathrm{~K}$ in vacuum. X-ray photoelectron spectroscopy (XPS) analysis was carried out in a Thermo Scientific Escalab 250 XI model (Thermo Fisher Scientific, Waltham, MA, USA) with monochromatic Al K $\alpha$ radiation. The measurements were performed at room temperature and a pressure of $7.8 \times 10^{-8} \mathrm{mbar}$. The scans were measured at a pass energy of $25 \mathrm{eV}$ and a step size of $0.05 \mathrm{eV}$. In all experiments, $\mathrm{Ar}^{+}$ ion etching was used and the conditions were as follows: ion energy, $3000 \mathrm{eV}$; etch time, 60 seconds; and current, medium. Binding energies (BE) were calibrated to the $\mathrm{C} 1 \mathrm{~s}$ peak $(284.6 \mathrm{eV})$ and the spectra were examined with CasaXPS software (version 2.3.16 PR 1.6).

\subsection{Catalytic Ethanol Decomposition Experiments}

Ethanol decomposition was performed in gas phase in a continuous-flow, atmospheric- pressure reactor. Prior to reaction, the catalyst samples $(100 \mathrm{mg})$ were dried at $473 \mathrm{~K}$ under He and reduced with $\mathrm{H}_{2}$ at $873 \mathrm{~K}$ for $2 \mathrm{~h}$, followed by heating until reaching $973 \mathrm{~K}$ under He flow. The reactant mixture ( $5 \%$ ethanol and $95 \% \mathrm{He}, 100 \mathrm{~mL} \mathrm{~min}^{-1}$ ) was acquired by bubbling He through a saturator containing ethanol at $293 \mathrm{~K}$. The reactions were studied under isothermal conditions at $873 \mathrm{~K}$ for $13 \mathrm{~h}$. The ethanol and decomposition products were followed by gas chromatography (Varian 3400, Palo Alto, CA, USA) using Carboxen 1010 plot and Porabond Q capillary columns. Ethanol conversion (X) and hydrogen selectivity $(\mathrm{S})$ were determined employing the following equations, where $y_{j}$ is the molar fraction of compound $j$ in the exit stream:

$$
\begin{gathered}
X_{\mathrm{C}_{2} \mathrm{H}_{5} \mathrm{OH}}=\frac{y_{\mathrm{CO}}+y_{\mathrm{CH}_{4}}+y_{\mathrm{CO}_{2}}+2 y_{\mathrm{C}_{2} \mathrm{H}_{4} \mathrm{O}}}{2 y_{\mathrm{C}_{2} \mathrm{H}_{5} \mathrm{OH}}+y_{\mathrm{CO}}+y_{\mathrm{CH}_{4}}+y_{\mathrm{CO}_{2}}+2 y_{\mathrm{C}_{2} \mathrm{H}_{4} \mathrm{O}}} \times 100 \\
S_{\mathrm{H}_{2}}=\frac{y_{\mathrm{H}_{2}}}{y_{\mathrm{H}_{2}}+2 y_{\mathrm{CH}_{4}}+y_{\mathrm{H}_{2} \mathrm{O}}+2 y_{C_{2} \mathrm{H}_{4} \mathrm{O}}} \times 100
\end{gathered}
$$

\subsection{In Situ Diffuse Reflectance Infrared Spectroscopy (DRIFTS) Measurements}

Diffuse reflectance infrared spectroscopy (DRIFTS) analysis was carried out in an FTIR spectrometer (VERTEX 70-Bruker, Billerica, MA, USA) with a DRIFTS cell (Harrick Scientific, HVC-DRP-4, New York, NY, USA) and a praying mantis mirror assembly (Harrick Scientific). Prior to $\mathrm{C}_{2} \mathrm{H}_{5} \mathrm{OH}$-DRIFTS analysis, the passivated catalysts were dried at $473 \mathrm{~K}$ under He flow for $30 \mathrm{~min}$, reduced at $673 \mathrm{~K}$ under $\mathrm{H}_{2}$ flow $\left(30 \mathrm{~mL} \mathrm{~min}^{-1}\right)$, and cooled under He flow $\left(30 \mathrm{~mL} \mathrm{~min}^{-1}\right)$ until reaching $303 \mathrm{~K}$. At this temperature, a background interferogram was collected, as well as at 573, 473, 373, and $303 \mathrm{~K}$. The adsorption of ethanol was conducted at $293 \mathrm{~K}$ using an ethanol/He mixture, which was obtained by flowing He through a saturator ethanol at $293 \mathrm{~K}$. After adsorption, the samples were purged under He flow and a new interferogram was taken, which related to the background reference to acquire the spectrum of adsorbed ethanol.

\subsection{Spent Catalyst Characterization}

The amount of the coke deposited on the spent catalysts was quantified by thermogravimetry (TGA/DTA, Shimadzu-60H, Kyoto, Japan) through the mass loss during the analysis. The samples were dried up to $423 \mathrm{~K}$ for $1 \mathrm{~h}$ in He flow $\left(30 \mathrm{~mL} \mathrm{~min}^{-1}\right)$ to remove water and physisorbed species on the catalyst surface and cooled under He flow until reaching $303 \mathrm{~K}$. At this temperature, TGA was carried out under airflow until reaching $1200 \mathrm{~K}\left(10 \mathrm{~K} \mathrm{~min}^{-1}\right)$. Quantification of carbon was calculated according to the following equation:

$$
\mathrm{C}=\mathrm{m}_{\text {coke }} / \mathrm{m}_{\text {spent catalyst }}
$$


The spent catalysts were studied by Raman spectroscopy using a Confocal Raman Microscope alpha300 (Witec, Ratingen, Germany) with a 50× objective lens, a laser with $532 \mathrm{~nm}$ wavelength, and 450 scans.

\section{Results}

\subsection{Catalyst Characterization}

Diffractograms of passivated catalysts synthesized by the Pechini method are shown in Figure 1. The fresh catalyst with $x=0$ showed six diffraction angles $(2 \theta)$ at $23.2,32.9,33.3,40.7,47.5$, and 59.0 $0^{\circ}$ related to the (012), (110), (104), (202), (024), and (214) respective crystal planes of rhombohedral $\mathrm{LaCoO}_{3}$ (JCPDS 48-0123). For the Ni-containing catalyst, these peaks are slightly displaced, which could be a consequence of the possible insertion of $\mathrm{Ni}$ into the structure. In addition, a diffraction line at $2 \theta \sim 32.7^{\circ}$ attributed to the $\mathrm{LaNiO}_{3}$ structure [24] was mainly detected for the $\mathrm{La}_{0.8} \mathrm{Ce}_{0.2} \mathrm{Ni}_{0.7} \mathrm{Co}_{0.3}$ precursor. This result is not surprising given the greater amount of nickel in this precursor. Strong peaks corresponding to $\mathrm{Co}_{2} \mathrm{O}_{3}, \mathrm{La}(\mathrm{OH})_{3}$, and $\mathrm{NiO}$ were also observed. Peaks detected at 31.8, 36.2, 44.9, 59.5, and $65.5^{\circ}$ are due to planes (2 20 ), ( $\left.\begin{array}{lll}3 & 1 & 1\end{array}\right),\left(\begin{array}{lll}4 & 0 & 0\end{array}\right),\left(\begin{array}{lll}5 & 1 & 1\end{array}\right)$, and (4 40 ), respectively, (JCPDS 65-3103) of the $\mathrm{Co}_{2} \mathrm{O}_{3}$ cubic phase, while those observed at $2 \theta$ of $15.8,28.1$, and $49.1^{\circ}$ (JCPDS 00-036-1841) are characteristic of $\mathrm{La}(\mathrm{OH})_{3}$. The diffraction lines corresponding to $\mathrm{NiO}(2 \theta=37.2$, 43.3, and 62.9 JCPDS 01-073-1519) appeared mainly in the precursor with higher nickel content $\left(\mathrm{La}_{0.8} \mathrm{Ce}_{0.2} \mathrm{Ni}_{0.7} \mathrm{Co}_{0.3}\right)$ although slightly shifted. The presence of these latter phases is an indication that there was possibly an excessive amount of cations that led to the segregation of these species, as has been reported by other authors [25-27]. The passivated $\mathrm{Ni}_{0.7} \mathrm{Co}_{0.3} / \mathrm{La}_{0.8} \mathrm{Ce}_{0.2}, \mathrm{Ni}_{0.4} \mathrm{Co}_{0.6} / \mathrm{La}_{0.8} \mathrm{Ce}_{0.2}$, and $\mathrm{Co} / \mathrm{La}_{0.8} \mathrm{Ce}_{0.2}$ catalysts (Figure 2) exhibited clear signals indexed at $2 \theta=28.6^{\circ}(111), 33.1^{\circ}(200), 47.6^{\circ}$ (2 20 ), and 56.5 (3 11 ) (JCPDS 081-0792) attributed to a fluorite-type structure of $\mathrm{CeO}_{2}$. Similarly, these diffractograms revealed the presence of peaks corresponding to $\mathrm{La}_{2} \mathrm{O}_{3}$ at 26.1, 29.1, 29.9, 39.64, 46, and $52^{\circ}$ (JCPDS 01-074-2430). The $\mathrm{La}(\mathrm{OH})_{3}$ phase was also detected after the reduction stage. Diffraction lines attributable to $\mathrm{Co}_{2} \mathrm{O}_{3}$ were still observed in the $\mathrm{Co} / \mathrm{La}_{0.8} \mathrm{Ce}_{0.2}$ catalyst after reduction, showing that this species was hardly reducible and probably the presence of $\mathrm{Ni}\left(\mathrm{Ni}_{0.7} \mathrm{Co}_{0.3} / \mathrm{La}_{0.8} \mathrm{Ce}_{0.2}\right.$, $\mathrm{Ni}_{0.4} \mathrm{Co}_{0.6} / \mathrm{La}_{0.8} \mathrm{Ce}_{0.2}$, and $\left.\mathrm{Ni}_{0.1} \mathrm{Co}_{0.9} / \mathrm{La}_{0.8} \mathrm{Ce}_{0.2}\right)$ favored its reduction. However, XRD signals were only observed for $\mathrm{Ni}_{0.1} \mathrm{Co}_{0.9} / \mathrm{La}_{0.8} \mathrm{Ce}_{0.2}$ systems due to metallic $\mathrm{Co}\left(2 \theta=44.3,51.8\right.$, and $\left.76.3^{\circ}\right)$ and $\mathrm{Ni}$ $\left(2 \theta=44.5,51.8\right.$, and $\left.76.5^{\circ}\right)$. It is possible that these peaks were not detectable for the other catalysts due to a high dispersion of these species, as confirmed by $\mathrm{H}_{2}$ chemisorption and TEM (Table 1).

Table 1. Structural parameters of supports and $\mathrm{Ni}_{1-\mathrm{x}} \mathrm{Co}_{\mathrm{x}} / \mathrm{La}_{0.8} \mathrm{Ce}_{0.2}$ catalysts.

\begin{tabular}{|c|c|c|c|c|c|c|c|}
\hline Catalysts & $\begin{array}{c}\text { Surface } \\
\text { Area BET } \\
\left(\mathrm{m}^{2} \mathrm{~g}^{-1}\right)\end{array}$ & $\begin{array}{c}\text { Pore } \\
\text { Volume } \\
\left(\mathrm{cm}^{3} \mathrm{~g}^{-1}\right)\end{array}$ & $\begin{array}{l}\text { Pore Size } \\
\quad(\mathrm{nm})\end{array}$ & $\begin{array}{c}\text { Dispersion } \\
(\%)\end{array}$ & $\begin{array}{c}\text { Particle } \\
\text { Size }^{a} \\
(n m)\end{array}$ & $\begin{array}{l}\text { Particle } \\
\text { Size }^{b} \\
(\mathrm{~nm})\end{array}$ & $\begin{array}{c}\text { Acidity } \\
\left(\mathrm{mol} \mathrm{NH}_{3}\right. \\
\left.\text { gcat }^{-1}\right)\end{array}$ \\
\hline $\mathrm{Ni}_{0.7} \mathrm{Co}_{0.3} / \mathrm{La}_{0.8} \mathrm{Ce}_{0.2}$ & 33 & 0.13 & 25 & 21 & 4.8 & 9.1 & 0.04 \\
\hline $\mathrm{Ni}_{0.4} \mathrm{Co}_{0.6} / \mathrm{LaO}_{0.8} \mathrm{Ce}_{0.2}$ & 16 & 0.05 & 28 & 10 & 10 & 5.9 & 0.47 \\
\hline $\mathrm{Ni}_{0.1} \mathrm{Co}_{0.9} / \mathrm{La}_{0.8} \mathrm{Ce}_{0.2}$ & 14 & 0.04 & 31 & 6 & 17 & 12.4 & 0.23 \\
\hline $\mathrm{Co} / \mathrm{La}_{0.8} \mathrm{Ce}_{0.2}$ & 23 & 0.06 & 45 & 3 & 33 & 16.8 & 0.35 \\
\hline
\end{tabular}

${ }^{a}$ Determined by $\mathrm{H}_{2}$ chemisorption; ${ }^{\mathrm{b}}$ Determined by TEM.

Figure 3 shows the $\mathrm{H}_{2}$-TPR profiles of the supported Ni-Co catalysts. The reduction profile of all oxidized catalysts exhibited two peaks in the range between $470-700 \mathrm{~K}$ and $700-923 \mathrm{~K}$ with different maximum temperatures between them.

The first peak can be related to the reduction of $\mathrm{Co}^{3+}$ to $\mathrm{Co}^{2+}$, at the same time as the $\mathrm{Ni}^{3+}$ to $\mathrm{Ni}^{2+}$, coming from the perovskite structure, as has already been reported [26-28]. Subsequently, the second peak corresponds to the reduction of $\mathrm{Co}^{2+}$ to $\mathrm{Co}^{0}$ and/or $\mathrm{Ni}^{2+}$ to $\mathrm{Ni}^{0}$ of the same structure. When the amount of $\mathrm{Ni}$ increases, the reduction temperature is shifted to lower temperatures $\left(\mathrm{Ni}_{0.7} \mathrm{Co}_{0.3} / \mathrm{La}_{0.8} \mathrm{Ce}_{0.2}\right.$ and $\mathrm{Ni}_{0.4} \mathrm{Co}_{0.6} / \mathrm{La}_{0.8} \mathrm{Ce}_{0.2}$ ), which can be ascribed to the reduction of $\mathrm{Ni}^{2+}$ to $\mathrm{Ni}^{0}$ into the nickel oxide 
phase $[26,27,29]$ found by $X R D$. In the $\mathrm{Co} / \mathrm{La}_{0.8} \mathrm{Ce}_{0.2}$ catalyst, the lowest observed reduction temperature $(\sim 573 \mathrm{~K})$ can also be associated with the reduction of $\mathrm{Co}_{3} \mathrm{O}_{4} \rightarrow \mathrm{CoO} \rightarrow \mathrm{Co}$ [29]. Based on XRD and TPR results, after reduction at $873 \mathrm{~K}$, the perovskite structure was destroyed, and metal Co-Ni particles were supported over lanthanum-cerium oxides. Total acidity of the samples was determined by $\mathrm{NH}_{3}$-TPD (Figure 4), and the results are shown in Table 1.
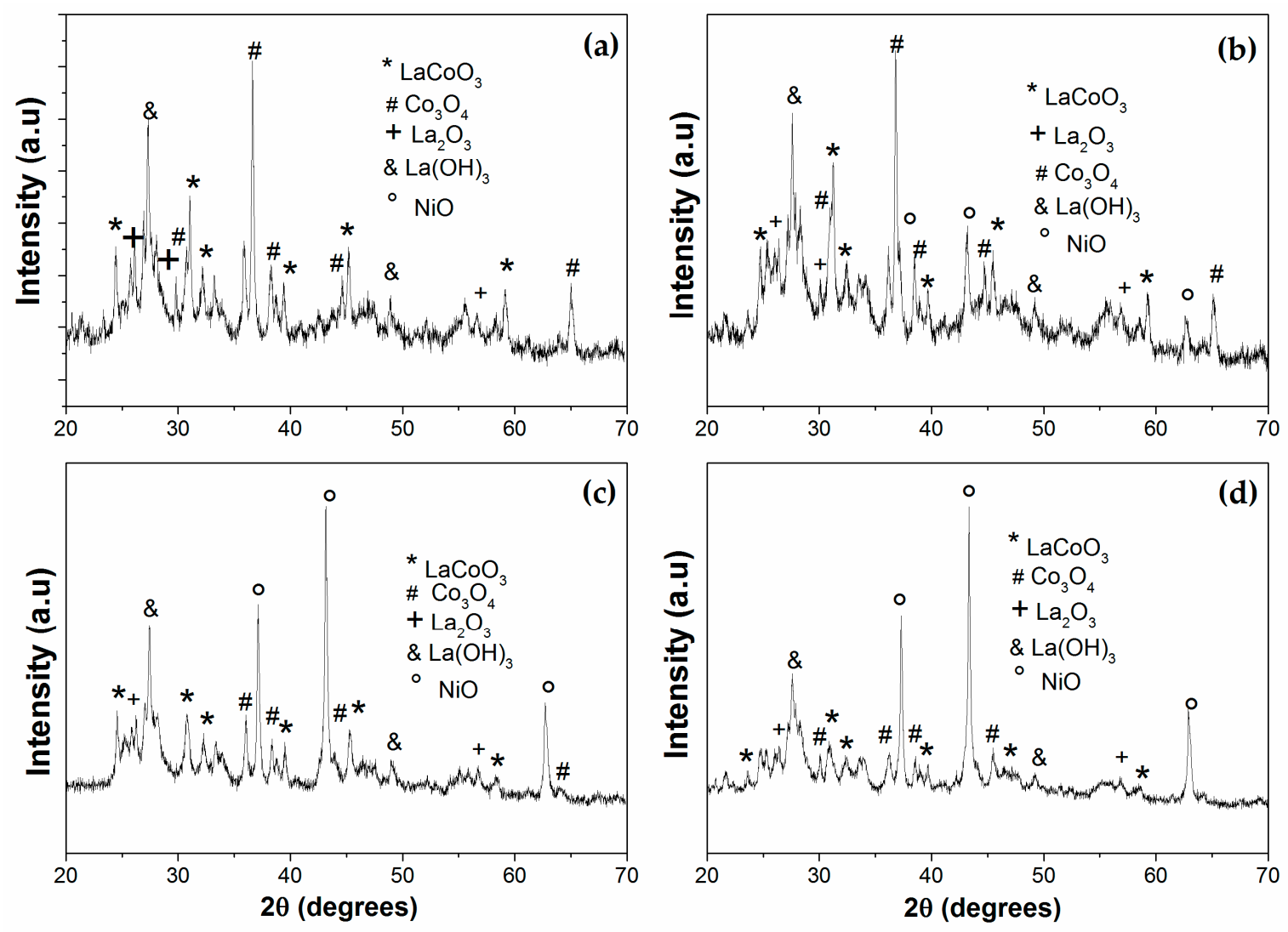

Figure 1. X-ray diffraction patterns of calcined catalysts: (a) $\mathrm{Co} / \mathrm{La}_{0.8} \mathrm{Ce}_{0.2} ;$ (b) $\mathrm{Ni}_{0.1} \mathrm{Co}_{0.9} / \mathrm{La}_{0.8} \mathrm{Ce}_{0.2} ;$ (c) $\mathrm{Ni}_{0.4} \mathrm{Co}_{0.6} / \mathrm{La}_{0.8} \mathrm{Ce}_{0.2}$; and (d) $\mathrm{Ni}_{0.7} \mathrm{Co}_{0.3} / \mathrm{La}_{0.8} \mathrm{Ce}_{0.2}$.

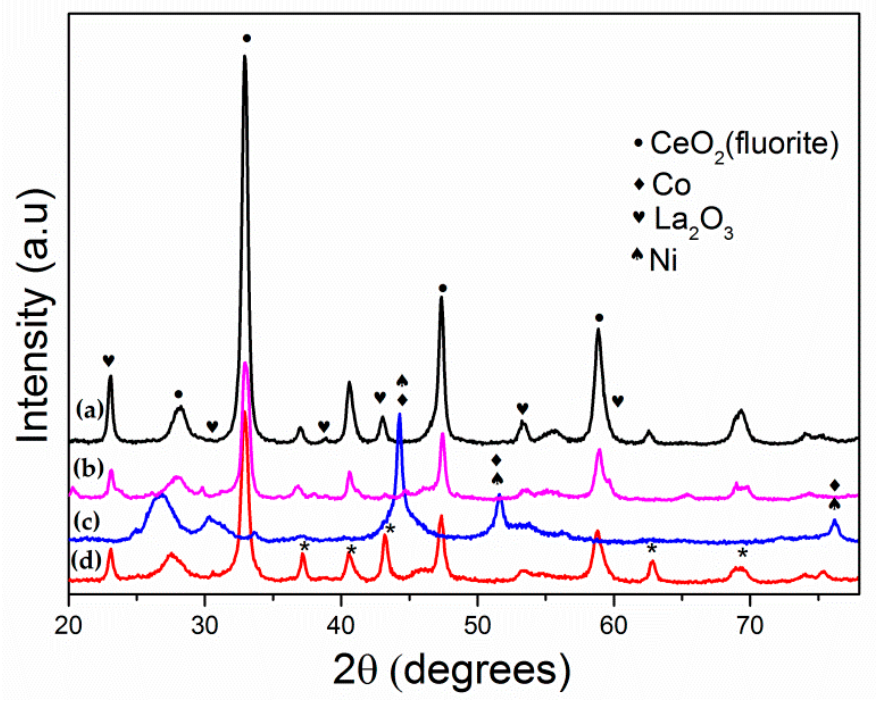

Figure 2. X-ray diffraction patterns of passivated catalysts: (a) $\mathrm{Ni}_{0.7} \mathrm{Co}_{0.3} / \mathrm{La}_{0.8} \mathrm{Ce}_{0.2}$, (b) $\mathrm{Ni}_{0.4} \mathrm{Co}_{0.6} /$ $\mathrm{La}_{0.8} \mathrm{Ce}_{0.2}$, (c) $\mathrm{Ni}_{0.1} \mathrm{Co}_{0.9} / \mathrm{La}_{0.8} \mathrm{Ce}_{0.2}$, and (d) $\mathrm{Co} / \mathrm{La}_{0.8} \mathrm{Ce}_{0.2}$. 


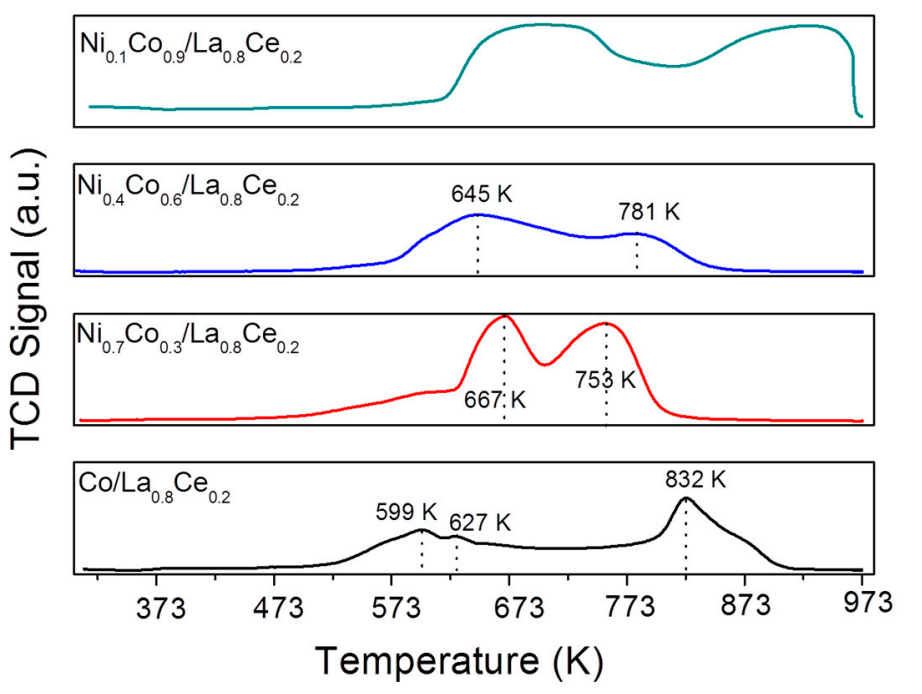

Figure 3. Temperature-programmed reduction (TPR) profiles of the prepared catalysts.

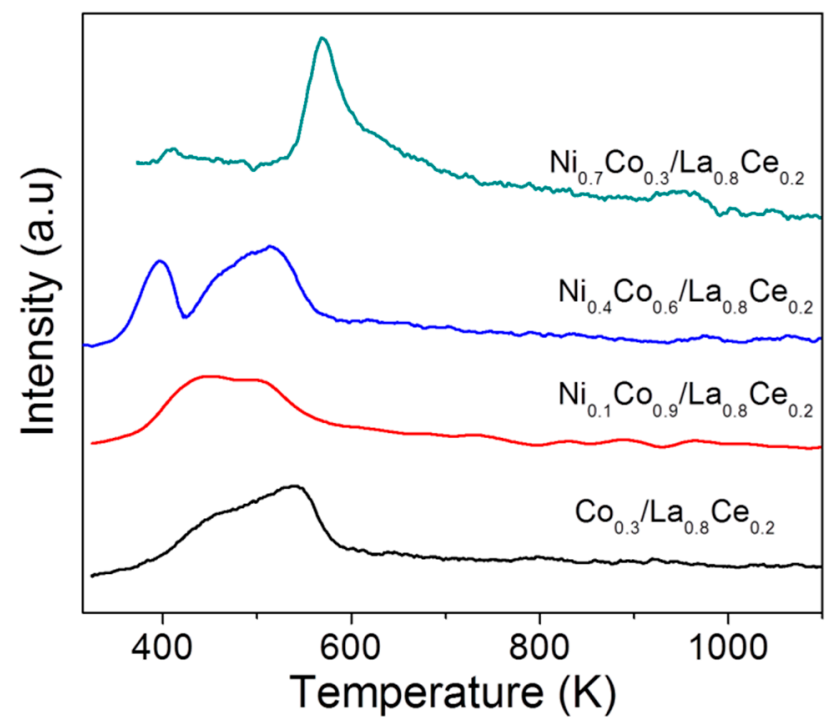

Figure 4. $\mathrm{NH}_{3}$-TPD profiles of the prepared catalysts $\mathrm{Co}_{\mathrm{x}} \mathrm{Ni}_{1-\mathrm{x}} / \mathrm{La}_{0.8} \mathrm{Ce}_{0.2}$ for acidity determination.

Generally, the strength of acid sites is classified depending on the temperature in which the desorption peaks appear as follows: weak (<473 K), medium (between 473 and $673 \mathrm{~K}$ ) and strong (>673 K). The $\mathrm{Co} / \mathrm{La}_{0.8} \mathrm{Ce}_{0.2}, \mathrm{Ni}_{0.1} \mathrm{Co}_{0.9} / \mathrm{La}_{0.8} \mathrm{Ce}_{0.2}$, and $\mathrm{Ni}_{0.4} \mathrm{Co}_{0.6} / \mathrm{La}_{0.8} \mathrm{Ce}_{0.2}$ catalysts exhibited some signals corresponding to weak and intermediate acid sites, whereas the $\mathrm{Ni}_{0.7} \mathrm{Co}_{0.3} / \mathrm{La}_{0.8} \mathrm{Ce}_{0.2}$ system showed only intermediate acid sites.

Table 1 also shows the textural properties of catalysts studied. An increase in the cobalt loading in the bimetallic catalysts seems to decrease the surface area, thus $\mathrm{Ni}_{0.7} \mathrm{Co}_{0.3} / \mathrm{La}_{0.8} \mathrm{Ce}_{0.2}$ exhibited the highest surface $\left(33 \mathrm{~m}^{2} \mathrm{~g}^{-1}\right)$, whereas $\mathrm{Ni}_{0.1} \mathrm{Co}_{0.9} / \mathrm{La}_{0.8} \mathrm{Ce}_{0.2}$ had the lowest surface area $\left(14 \mathrm{~m}^{2} \mathrm{~g}^{-1}\right)$. The low surface area of the latter was probably due to the blocking of the support pores by cobalt particles. Figure 5 shows the $\mathrm{N}_{2}$ adsorption-desorption isotherms for all catalysts. The isotherms for the Ni-Co catalysts were type IV with $\mathrm{H} 3$ hysteresis, suggesting slit-shaped pores [30].

TEM micrographs with their corresponding histograms are presented in Figure 6. Particle sizes as determined by TEM are shown in Table 1. The presence of both metals had an effect on particle size-as the nickel content increased, the particle size decreased—as has been reported previously [31]. This could be an indication of interaction between metals. As the histograms show, for catalysts with 
low or no Ni content, a wide size distribution was observed, contrary to that observed for $\mathrm{Ni}>0.1$. The presence of both metals resulted in small particle sizes in a narrow distribution. These results were confirmed by $\mathrm{H}_{2}$ chemisorption measurements.

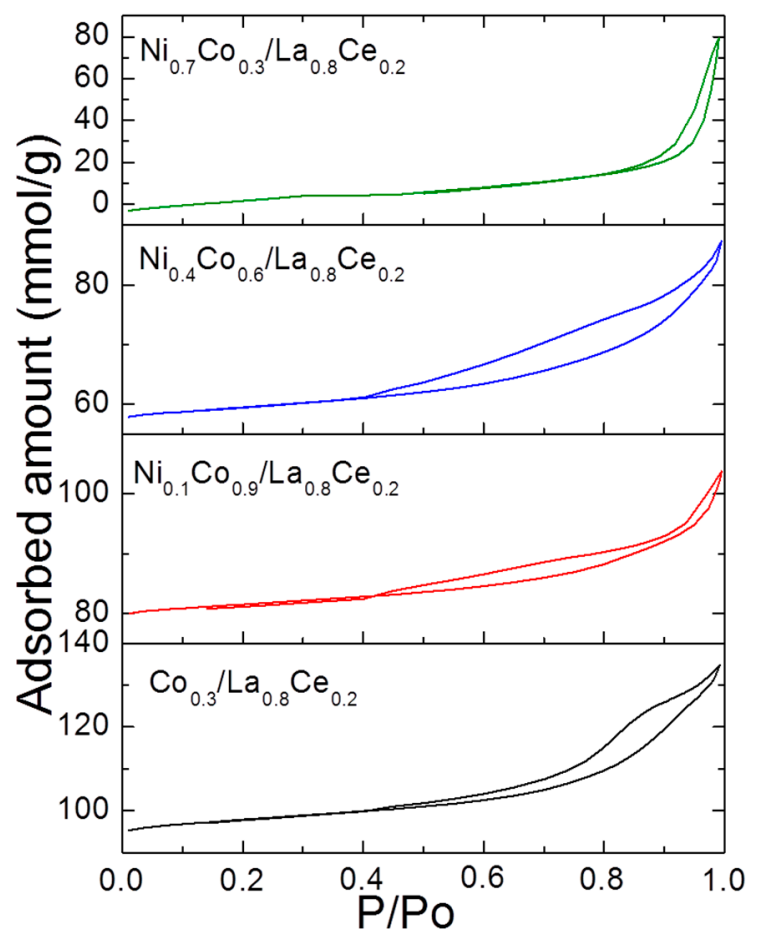

Figure 5. $\mathrm{N}_{2}$ adsorption-desorption isotherms for $\mathrm{Ni}_{1-\mathrm{x}} \mathrm{Co}_{\mathrm{x}} / \mathrm{La}_{0.8} \mathrm{Ce}_{0.2}$ catalysts.
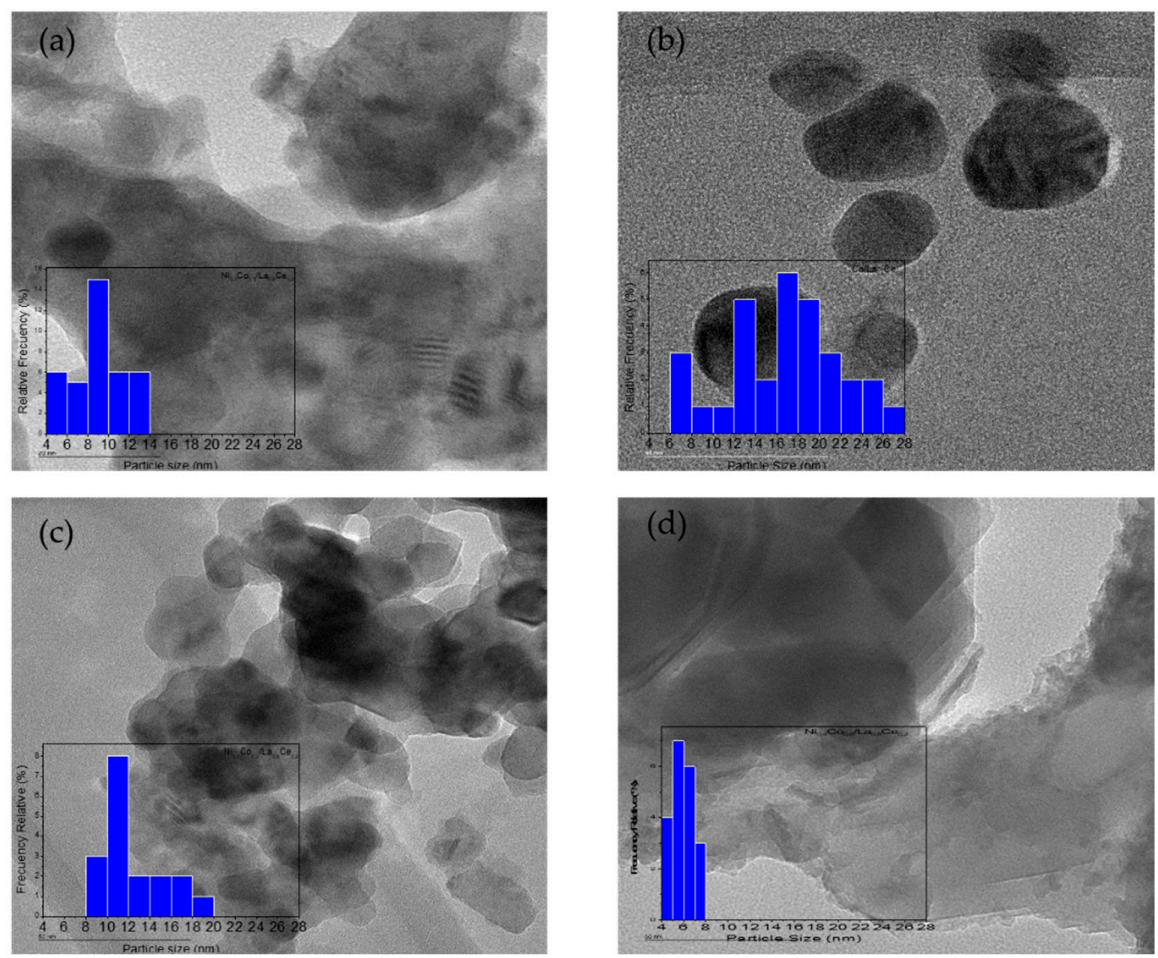

Figure 6. TEM micrographs of $\mathrm{Ni}_{1-\mathrm{x}} \mathrm{Co}_{\mathrm{x}} / \mathrm{La}_{0.8} \mathrm{Ce}_{0.2}$ catalysts: (a) $\mathrm{Ni}_{0.7} \mathrm{Co}_{0.3} / \mathrm{La}_{0.8} \mathrm{Ce}_{0.2} ;$ (b) $\mathrm{Co} / \mathrm{La}_{0.8} \mathrm{Ce}_{0.2}$; (c) $\mathrm{Ni}_{0.1} \mathrm{Co}_{0.9} / \mathrm{La}_{0.8} \mathrm{Ce}_{0.2} ;$ and (d) $\mathrm{Ni}_{0.4} \mathrm{Co}_{0.6} / \mathrm{La}_{0.8} \mathrm{Ce}_{0.2}$. 
The XPS spectra for $\mathrm{Ni}_{1-\mathrm{x}}-\mathrm{Co}_{x}$ catalysts are shown in Figures 7-10. Signal deconvolution of the $\mathrm{Ni}$ $2 \mathrm{p}_{3 / 2}$ core-level region (Figure 7) led to four main peaks, centered at 850.8, 853.1, 855.1, and $861.4 \mathrm{eV}$. The peaks at $\sim 853.1 \mathrm{eV}$ (main peak) and $861.4 \mathrm{eV}$ (satellite peak) correspond to $\mathrm{NiO}$, while the peak at 855.1 was assigned to $\mathrm{Ni}(\mathrm{OH})_{2}[32,33]$. According to the literature, the Ni metal $2 \mathrm{p}_{3 / 2}$ peak position is found at around $852.3 \pm 0.4 \mathrm{eV}$ [31,34]; however, in this study, this peak underwent a shift around $0.8-1.8 \mathrm{eV}$. This result could be related to a possible Ni-Co interaction. For $\mathrm{Co}$, deconvolution curves of Co2p binding energy range from $770 \mathrm{eV}$ to $810 \mathrm{eV}$ and are shown in Figure 8.
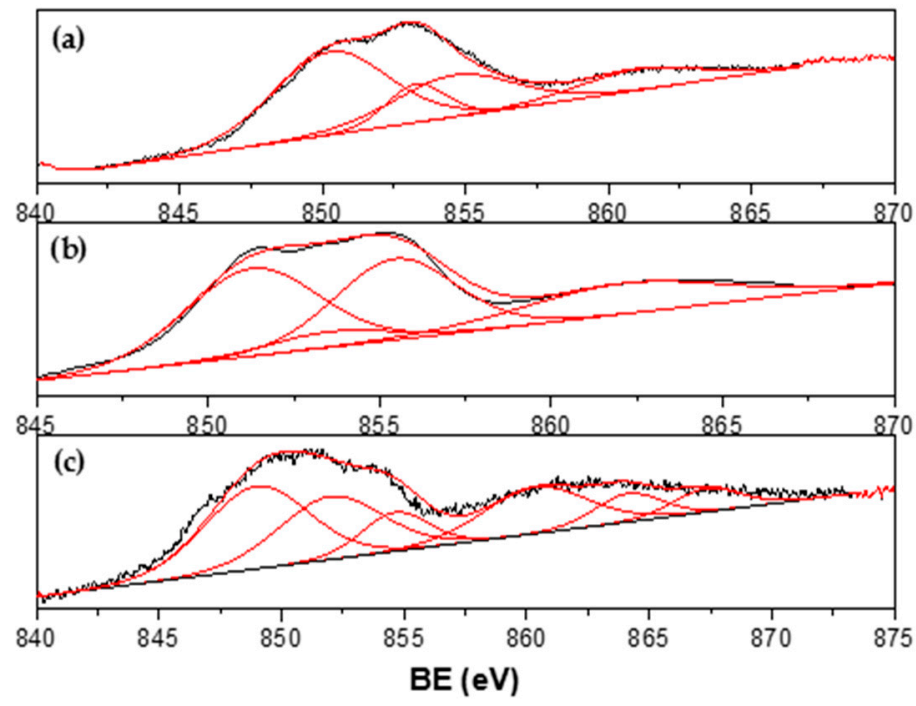

Figure 7. $\mathrm{Ni} 2 \mathrm{p}$ XPS spectra of (a) $\mathrm{Ni}_{0.1} \mathrm{Co}_{0.9} / \mathrm{La}_{0.8} \mathrm{Ce}_{0.2} ;$ (b) $\mathrm{Ni}_{0.4} \mathrm{Co}_{0.6} / \mathrm{La}_{0.8} \mathrm{Ce}_{0.2} ;$ and (c) $\mathrm{Ni}_{0.7} \mathrm{Co}_{0.3} / \mathrm{La}_{0.8} \mathrm{Ce}_{0.2}$.

Signals obtained are consistent with $\mathrm{Co}$ metallic and $\mathrm{Co}$ in $\mathrm{Co}^{2+}$ and $\mathrm{Co}^{3+}$ oxidation states, as has been reported [34-37]. A peak detected around $777.6 \mathrm{eV}$ could be assigned to metallic Co but shifted approximately $0.6 \mathrm{eV}$ from the reported value [34-37], which confirms the results found for Ni XPS. $\mathrm{Co}^{2 *}$ and/or $\mathrm{Co}^{3+}$ species were identified by the presence of peaks around $780 \mathrm{eV}$ and the characteristic strong satellite peak at around $786 \mathrm{eV}$ ascribed to $\mathrm{CoO}$. XPS results confirmed the presence of metallic particles of $\mathrm{Ni}$ and $\mathrm{Co}$ and may suggest an interaction between them.
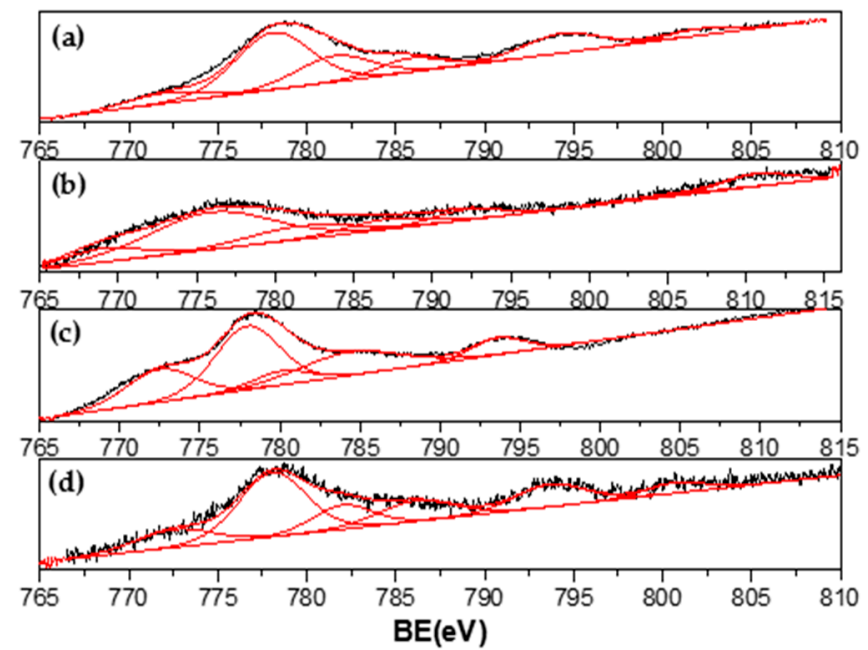

Figure 8. Co 2p XPS spectra of (a) $\mathrm{Co} / \mathrm{La}_{0.8} \mathrm{Ce}_{0.2} ;(\mathbf{b}) \mathrm{Ni}_{0.1} \mathrm{Co}_{0.9} / \mathrm{La}_{0.8} \mathrm{Ce}_{0.2} ;(\mathbf{c}) \mathrm{Ni}_{0.4} \mathrm{Co}_{0.6} / \mathrm{La}_{0.8} \mathrm{Ce}_{0.2} ;$ and (d) $\mathrm{Ni}_{0.7} \mathrm{Co}_{0.3} / \mathrm{La}_{0.8} \mathrm{Ce}_{0.2}$. 
Ce $3 d_{3 / 2,5 / 2}$ spectra (Figure 9) are composed of multiplets corresponding to the spin-orbit split $3 d_{5 / 2}$ and $3 \mathrm{~d}_{3 / 2}$ core holes for $\mathrm{Ce}^{4+}$ ions. The binding energy located around 917 and $898.3 \mathrm{eV}$ were attributed to a Ce $3 \mathrm{~d}^{9} 4 \mathrm{f}^{0} \mathrm{O} 2 \mathrm{p}^{6}$ final state, being the first peak attributed to $\mathrm{Ce}^{4+}$ ions. The other peaks found at $901.3,882.7,907.3$, and $888.5 \mathrm{eV}$ are due to $\mathrm{Ce} 3 \mathrm{~d}^{9} 4 \mathrm{f}^{2} \mathrm{O} 2 \mathrm{p}^{4}$ and $3 \mathrm{~d}^{9} 4 \mathrm{f}^{1}$ final states [38,39]. These results indicate that the surface of the catalysts are composed of $\mathrm{CeO}_{2}$ oxides; however, a broadening or shoulder observed in spectra at about 885.3 and $903.8 \mathrm{eV}$ reveals that $\mathrm{Ce}^{3+}$ ions were also present on the support surface [40]. These peaks are the result of a Ce $3 d^{9} 4 f^{1} \mathrm{O} 2 \mathrm{p}^{6}$ final state [39]. The La $3 \mathrm{~d}$ spectra for $\mathrm{Ni}_{1-\mathrm{x}} \mathrm{Co}_{\mathrm{x}} / \mathrm{La}_{0.8} \mathrm{Ce}_{0.2}$ catalysts (Figure 10) consist of two doublets corresponding to La $3 \mathrm{~d}_{5 / 2}$ and $3 \mathrm{~d}_{3 / 2}$ core levels observed at 833.1 and $849.5 \mathrm{eV}$, respectively, and the satellite split to $4.2 \mathrm{eV}$ reported for $\mathrm{La}_{2} \mathrm{O}_{3}[41,42]$. XPS results confirmed that the support surface is composed of $\mathrm{La}_{2} \mathrm{O}_{3}$ and $\mathrm{CeO}_{2}$ oxides.
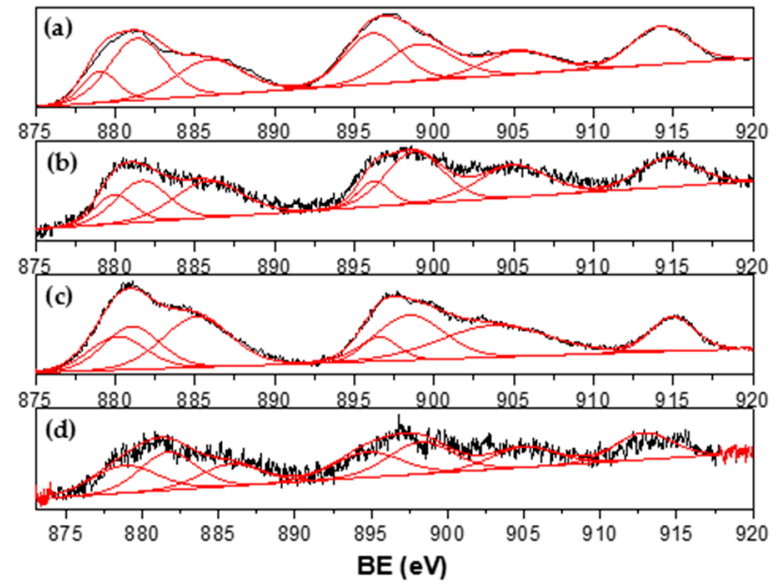

Figure 9. $\mathrm{Ce} 3 \mathrm{~d}_{3 / 2,5 / 2}$ XPS spectra of supported $\mathrm{Ni}_{1-\mathrm{x}} \mathrm{Co}_{\mathrm{x}} / \mathrm{La}_{0.8} \mathrm{Ce}_{0.2}$ catalysts. (a) $\mathrm{Co}$; (b) $\mathrm{Ni}_{0.1} \mathrm{Co}_{0.9}$; (c) $\mathrm{Ni}_{0.4} \mathrm{Co}_{0.6} ;$ and $(\mathbf{d}) \mathrm{Ni}_{0.7} \mathrm{Co}_{0.3}$.
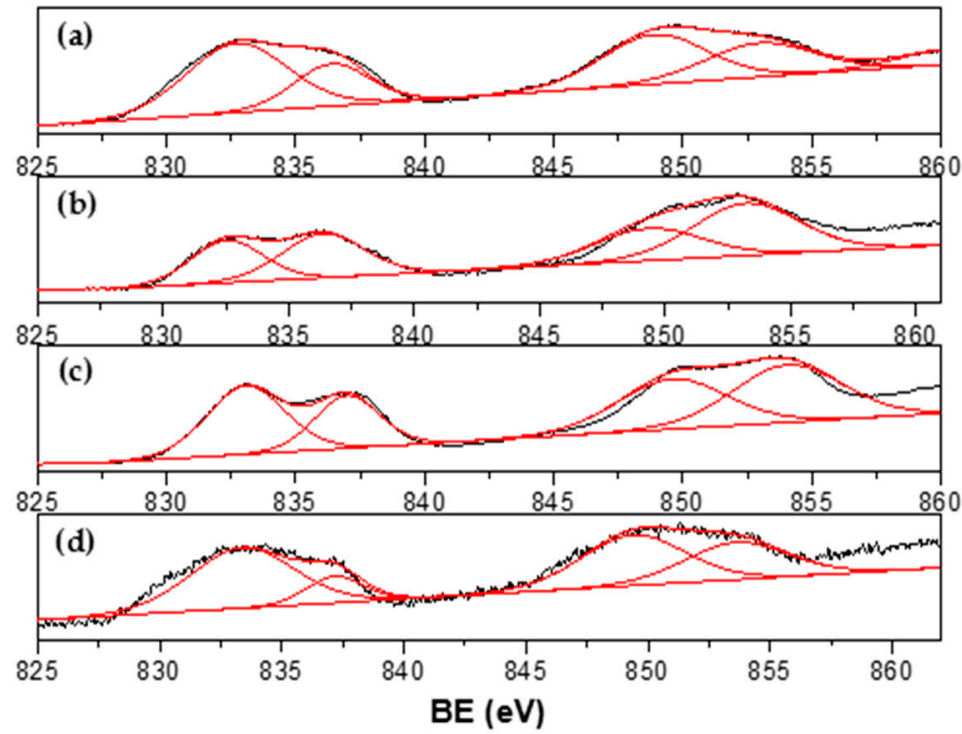

Figure 10. La $3 \mathrm{~d}$ spectra of $\mathrm{Ni}_{1-\mathrm{x}} \mathrm{Co}_{\mathrm{x}} / \mathrm{La}_{0.8} \mathrm{Ce}_{0.2}$ catalysts. (a) $\mathrm{Co}$; (b) $\mathrm{Ni}_{0.1} \mathrm{Co}_{0.9} ;$ (c) $\mathrm{Ni}_{0.4} \mathrm{Co}_{0.6}$; and (d) $\mathrm{Ni}_{0.7} \mathrm{Co}_{0.3}$.

\subsection{Evaluation of Adsorbed Species on the Catalyst Surface During Ethanol Decomposition by DRIFT}

Adsorbed species on the catalyst surface during ethanol decomposition from 303 to $673 \mathrm{~K}$ were evaluated by DRIFT spectroscopy (Figure 11). Ethanol adsorbed through ethoxy species on the surface catalysts. The ethoxy species is represented by bands at $2980 \mathrm{~cm}^{-1}$ (anti-symmetric $\left.v_{\mathrm{as}} \mathrm{CH}_{3}\right), 2900 \mathrm{~cm}^{-1}$ 
(symmetric $\left.v_{\mathrm{s}} \mathrm{CH}_{3}\right), 1060 \mathrm{~cm}^{-1}$ (symmetric $v_{\mathrm{s}} \mathrm{C}-\mathrm{O}$ ), and $1400 \mathrm{~cm}^{-1}\left(\delta_{\mathrm{s}} \mathrm{CH}_{3}\right)$, and its formation on the catalyst surface is due to the scission of the $\mathrm{O}-\mathrm{H}$ bond. When the temperature rose, band intensities were reduced probably due to the transformation of ethoxy species. At $473 \mathrm{~K}$, bands at $1765 \mathrm{~cm}^{-1}$ and $1560 \mathrm{~cm}^{-1}$ corresponding to $v_{\mathrm{s}}(\mathrm{CO})$ and $v_{\mathrm{as}}(\mathrm{COO})$ appeared, which can be due to dehydrogenation from ethoxy species leading to adsorbed acetaldehyde and/or acetate. Acetaldehyde may be dehydrogenated to acetyl species, and this intermediate may undergo support-induced oxidation to acetate species by both $\mathrm{O}_{\text {support }}$ or $\mathrm{OH}_{\text {support, }}$ as has been reported [43-45]. This can be favored on supports of redox oxides as $\mathrm{CeO}_{2}$.

$$
\begin{gathered}
\mathrm{CH}_{3} \mathrm{CH}_{2} \mathrm{O}_{a d s} \rightarrow \mathrm{CH}_{3} \mathrm{CHO}_{a d s}+\mathrm{H}_{2} \\
\mathrm{CH}_{3} \mathrm{CH}_{2} \mathrm{O}_{a d s} \rightarrow \mathrm{CH}_{3} \mathrm{CO}_{a d s} \rightarrow \mathrm{CH}_{3} \mathrm{COO}_{a d s}
\end{gathered}
$$

(a)

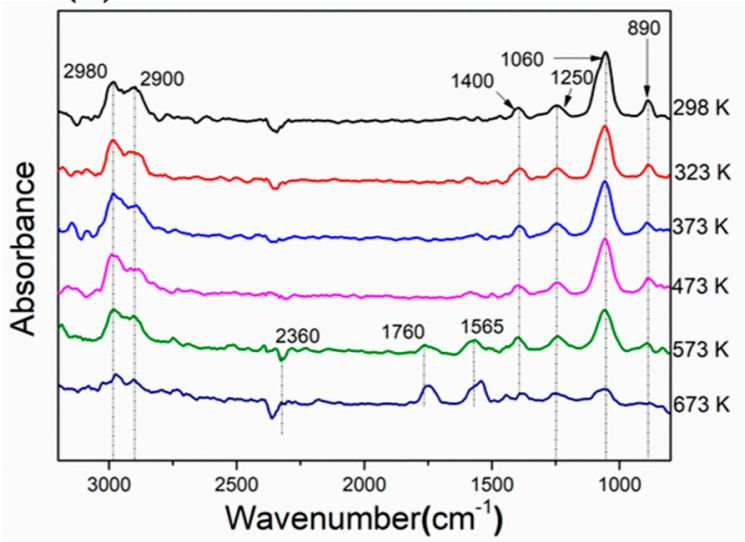

(c)

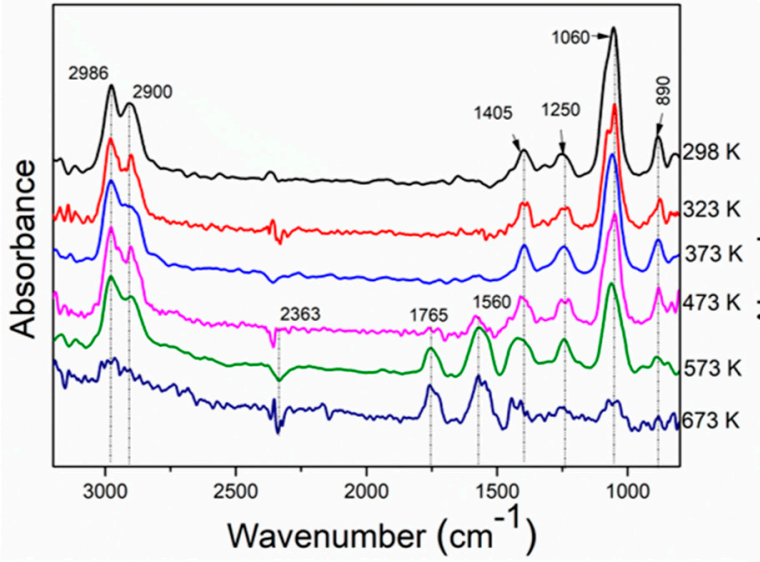

(b)

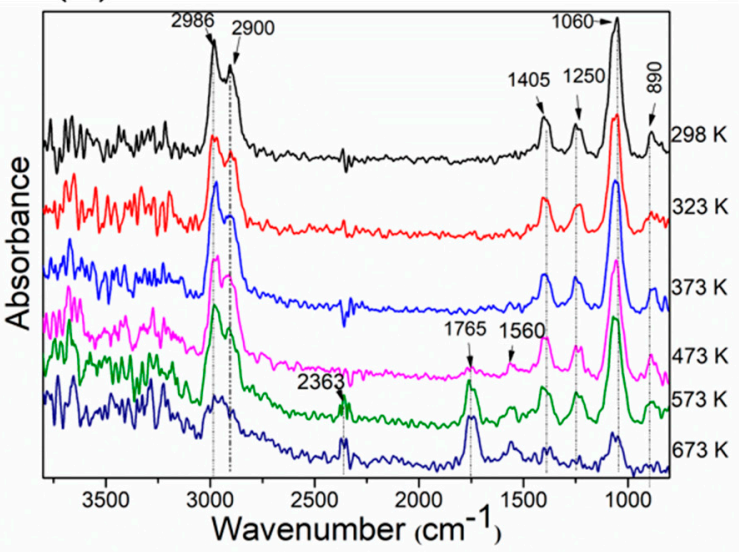

(d)

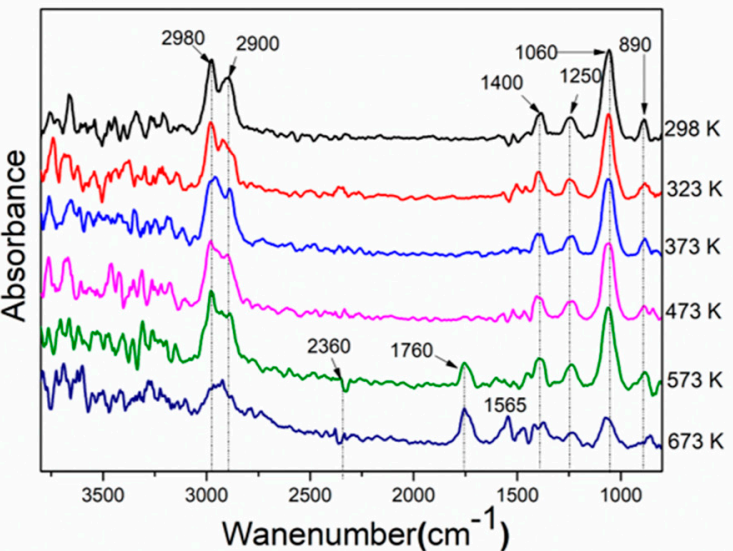

Figure 11. Diffuse reflectance infrared spectroscopy (DRIFT) spectra of ethanol decomposition collected for supported $\mathrm{Ni}_{1-\mathrm{x}} \mathrm{Co}_{\mathrm{x}} / \mathrm{La}_{0.8} \mathrm{Ce}_{0.2}$ catalysts. (a) $\mathrm{Co}$; (b) $\mathrm{Ni}_{0.1} \mathrm{Co}_{0.9} ;$ (c) $\mathrm{Ni}_{0.4} \mathrm{Co}_{0.6}$; and (d) $\mathrm{Ni}_{0.7} \mathrm{Co}_{0.3}$.

As temperature rises, band intensities associated with ethoxy species drop, suggesting their conversion with the concomitant rising of bands associated with acetaldehyde and/or acetates. As can be observed for $\mathrm{Ni}_{0.1} \mathrm{Co}_{0.9}$ and $\mathrm{Ni}_{0.4} \mathrm{Co}_{0.6}$, these species rose at lower temperatures. On the other hand, acetate formation was more favored on $\mathrm{Co}$ and $\mathrm{Ni}_{0.4} \mathrm{Co}_{0.6}$, which was confirmed by the low intensities of signals for C-H stretching (2800-3050 $\left.\mathrm{cm}^{-1}\right)$. Conversely, the band attributed to acetaldehyde was more pronounced for $\mathrm{Ni}_{0.1} \mathrm{Co}_{0.9}$ and $\mathrm{Ni}_{0.7} \mathrm{Co}_{0.3}$. Both acetaldehyde and acetates can be decomposed leading to the formation of $\mathrm{CO}_{2} / \mathrm{CO}$ and $\mathrm{CH}_{4}$ (Equations (6) and (7)), and the bands at $2363 \mathrm{~cm}^{-1}$ and $3017 \mathrm{~cm}^{-1}$, respectively, confirm their presence. Since the goal is that ethanol decomposition should address the selective generation of $\mathrm{H}_{2}$, the formation and decomposition of acetaldehyde and acetates are undesirable reactions. In addition, acetates can remain adsorbed on catalyst-blocking 
catalytic sites [22]. All catalysts showed signals attributable to these species even at high temperature, although the acetate signal on $\mathrm{Ni}_{0.7} \mathrm{Co}_{0.3}$ was less significant, which could point at a higher stability of this catalyst.

$$
\begin{aligned}
\mathrm{CH}_{3} \mathrm{CHO} & \rightarrow \mathrm{CH}_{4}+\mathrm{CO}_{a d s} \\
\mathrm{CH}_{3} \mathrm{COO}_{a d s} & \rightarrow \mathrm{CH}_{3(a d s)}+\mathrm{CO}_{2 a d s}
\end{aligned}
$$

\subsection{Ethanol Decomposition Catalytic Tests}

The initial rate of reaction $\left(-r_{a}\right)_{0}$ for the ethanol decomposition was determined considering an irreversible, pseudo-first-order chemical reaction under isothermal conditions (973 K). The results are shown in Table 2. These rate values decreased in the following sequence: $\mathrm{Ni}_{0.7} \mathrm{Co}_{0.3} / \mathrm{La}_{0.8} \mathrm{Ce}_{0.2}$ $>\mathrm{Ni}_{0.4} \mathrm{Co}_{0.6} / \mathrm{La}_{0.8} \mathrm{Ce}_{0.2}>\mathrm{Ni}_{0.1} \mathrm{Co}_{0.9} / \mathrm{La}_{0.8} \mathrm{Ce}_{0.2}>\mathrm{Co} / \mathrm{La}_{0.8} \mathrm{Ce}_{0.2}$. This behavior indicated that catalysts with high $\mathrm{Ni}$ content had a greater capacity to decompose ethanol than the systems having a low $\mathrm{Ni}$ content or no Ni. A different behavior was observed when the turnover frequency (TOF) was calculated; $\mathrm{Co} / \mathrm{La}_{0.8} \mathrm{Ce}_{0.2}$ and $\mathrm{Ni}_{0.1} \mathrm{Co}_{0.9} / \mathrm{La}_{0.8} \mathrm{Ce}_{0.2}$ catalysts were the most active systems for ethanol decomposition at initial or clean conditions. The Weisz-Prater criterion $\left(\mathrm{C}_{\mathrm{WP}}\right)$, ethanol conversion, and hydrogen selectivity for the $\mathrm{Ni}_{1-x} \mathrm{Co}_{x} / \mathrm{La}_{0.8} \mathrm{Ce}_{0.2}$ catalysts were calculated, and the results are shown in Table 2. All catalysts exhibited $C_{W P}$ values lower than 0.3 ; therefore, the results indicate the absence of mass transfer effects in ethanol decomposition reactions.

The $\mathrm{Ni}_{0.7} \mathrm{Co}_{0.3} / \mathrm{La}_{0.8} \mathrm{Ce}_{0.2}$ and $\mathrm{Ni}_{0.4} \mathrm{Co}_{0.6} / \mathrm{LaO}_{0.8} \mathrm{Ce}_{0.2}$ systems exhibited a high level of conversion $\left(\geq 90 \%\right.$ ) in the first hour of reaction, whereas $\mathrm{Ni}_{0.1} \mathrm{Co}_{0.9} / \mathrm{La}_{0.8} \mathrm{Ce}_{0.2}$ and $\mathrm{Co} / \mathrm{La}_{0.8} \mathrm{Ce}_{0.2}$ showed conversions of ethanol of $74.6 \%$ and $65.4 \%$, respectively (Table 2$)$. These same catalysts $\left(\mathrm{Ni}_{0.7}\right.$ and $\left.\mathrm{Ni}_{0.4}\right)$ showed higher hydrogen selectivity than $\mathrm{Ni}_{0.1}$ and Co catalysts. The $\mathrm{H}_{2}$ selectivity for $\mathrm{Ni}_{0.7} \mathrm{Co}_{0.3} / \mathrm{La}_{0.8} \mathrm{Ce}_{0.2}$ was $75 \%$, whereas for $\mathrm{Co} / \mathrm{La}_{0.8} \mathrm{Ce}_{0.2}$ it was only $52.6 \%$. The fact that $\mathrm{Ni}_{0.7} \mathrm{Co}_{0.3} / \mathrm{La}_{0.8} \mathrm{Ce}_{0.2}$ presented higher activity and hydrogen selectivity in ethanol decomposition may be related to the dispersion, which may increase the active metal surface to participate in the transformation of ethanol.

Table 2. Initial rate of reaction, turnover frequency (TOF), Weisz-Prater criterion, conversion, and hydrogen selectivity for ethanol decomposition. Reaction conditions: total flow, $100 \mathrm{~mL} \mathrm{~min}^{-1}$ (5\%

\begin{tabular}{|c|c|c|c|c|c|}
\hline Catalysts & $\left(-r_{a}\right)_{0}\left(\mathrm{~mol} \mathrm{~g}^{-1} \mathrm{~s}^{-1}\right)$ & TOF $\left(s^{-1}\right)$ & $\mathrm{C}_{\mathrm{WP}}$ & $\begin{array}{l}\text { Ethanol Conversion } \\
(\%)\end{array}$ & $\begin{array}{c}\text { Hydrogen } \\
\text { Selectivity (\%) }\end{array}$ \\
\hline $\mathrm{Ni}_{0.7} \mathrm{Co}_{0.3} / \mathrm{La}_{0.8} \mathrm{Ce}_{0.2}$ & $6.2 \times 10^{-4}$ & 0.06 & $6.3 \times 10^{-3}$ & 98.4 & 75.0 \\
\hline $\mathrm{Ni}_{0.4} \mathrm{Co}_{0.6} / \mathrm{La0}_{0.8} \mathrm{Ce}_{0.2}$ & $5.6 \times 10^{-4}$ & 0.11 & $2.8 \times 10^{-3}$ & 90.0 & 64.5 \\
\hline $\mathrm{Ni}_{0.1} \mathrm{Co}_{0.9} / \mathrm{La}_{0.8} \mathrm{Ce}_{0.2}$ & $4.7 \times 10^{-4}$ & 0.15 & $2.8 \times 10^{-3}$ & 74.6 & 56.3 \\
\hline $\mathrm{Co} / \mathrm{La}_{0.8} \mathrm{Ce}_{0.2}$ & $4.1 \times 10^{-4}$ & 0.27 & $1.5 \times 10^{-3}$ & 65.4 & 52.6 \\
\hline
\end{tabular}
ethanol; $95 \% \mathrm{He}$ ); temperature of reaction, $973 \mathrm{~K}$; catalyst weight, $100 \mathrm{mg}$ at $1 \mathrm{~h}$ of reaction.

Figure 12 shows the catalytic stability in the ethanol decomposition at $973 \mathrm{~K}$ during $13 \mathrm{~h}$ time on stream. The conversion level decreased slightly after 4-5 h of reaction and, afterward, the conversion of ethanol stabilized to levels of activity $\geq 50 \%$. The observed decrease could be caused by the accumulation of carbon on the catalyst surface. Other products such as carbon monoxide, methane, carbon dioxide, water, and acetaldehyde were detected in the reaction of ethanol decomposition 


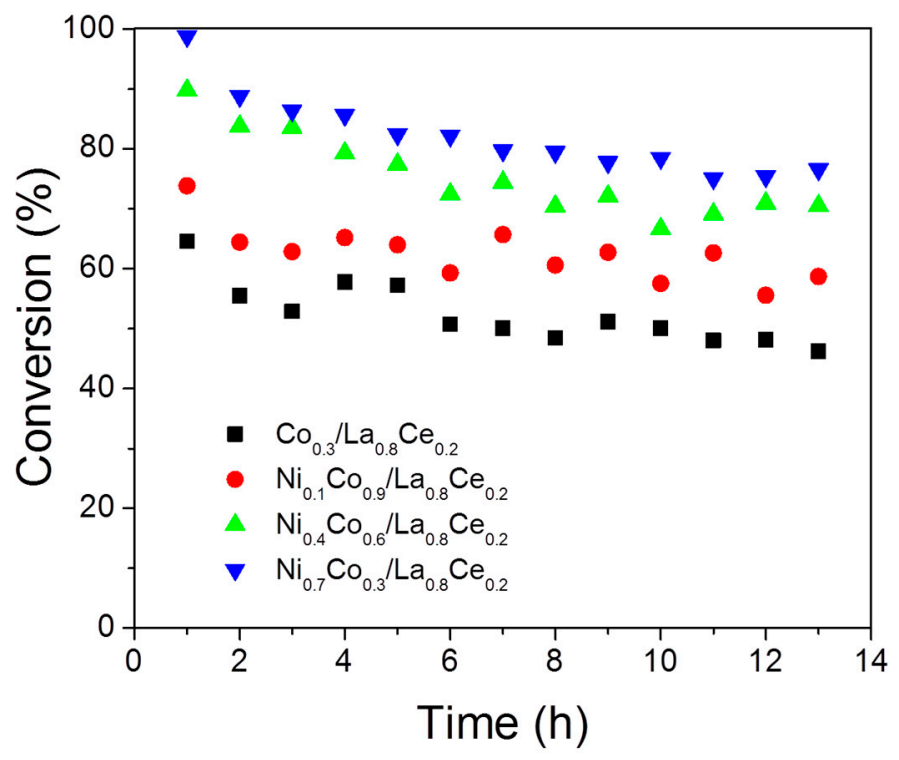

Figure 12. Stability tests in the reaction of ethanol decomposition over $\mathrm{Ni}_{1-\mathrm{x}} \mathrm{Co}_{\mathrm{x}} / \mathrm{La}_{0.8} \mathrm{Ce}_{0.2}$ catalysts.

Hydrogen, carbon monoxide, and methane were the principal products detected over the $\mathrm{Ni}_{1-\mathrm{x}} \mathrm{Co}_{\mathrm{x}} / \mathrm{La}_{0.8} \mathrm{Ce}_{0.2}$ systems. This behavior indicates that ethanol decomposition to hydrogen formation (Equation (1)) is favored at this temperature $(973 \mathrm{~K})$. Meanwhile, at $673 \mathrm{~K}$, the systems exhibited a high production of carbon dioxide as detected by DRIFTS of ethanol decomposition. At $973 \mathrm{~K}$, other compounds containing hydrogen such as methane, water, and acetaldehyde were also detected for all catalysts. The production of these compounds caused a decrease in hydrogen selectivity and their formation was related to both decomposition (Equation (1)), oxidation (Equation (4)), as well as the Boudouard (Equation (2)) and methanation (Equations (8) and (9)) reactions.

$$
\begin{gathered}
\mathrm{CO}+3 \mathrm{H}_{2} \rightarrow \mathrm{CH}_{4}+\mathrm{H}_{2} \mathrm{O} \\
\mathrm{CO}_{2}+4 \mathrm{H}_{2} \rightarrow \mathrm{CH}_{4}+2 \mathrm{H}_{2} \mathrm{O}
\end{gathered}
$$

Product distribution shown in Figure 13 confirms that other reactions besides the ethanol decomposition reaction (Equation (1)) occurred on all catalysts. $\mathrm{Ni}_{0.7}$ and $\mathrm{Ni}_{0.4}$ catalysts favored the dehydrogenation route leading to acetaldehyde (Equation (4)). The highest formation of acetaldehyde on $\mathrm{Ni}_{0.4}$ along with the presence of acetates detected even at high temperature by DRIFTS experiments indicates that this pathway reaction can be favored on this catalyst. This fact could be responsible for the high carbon deposition observed on this catalyst (Table 3). As has been reported [22], acetaldehyde can undergo an aldol condensation reaction yielding acetone (Equation (10)), which subsequently produces diacetone alcohol. Dehydration of this species gives rise to mesityl oxide (MO) (Equation (11)), whose oligomerization can lead to the formation of coke [22]. This indicates that, on the $\mathrm{Ni}_{0.4}$ catalyst, the promotion of $\mathrm{C}-\mathrm{C}$ bond cleavage is inefficient and the decarbonylation of acetaldehyde (Equation (6)) competes with aldol condensation and further formation of acetone. The same took place on the catalyst containing only $\mathrm{Co}$, where acetate species were detected by DRIFTS until high temperatures were reached.

$$
\begin{gathered}
2 \mathrm{CH}_{3} \mathrm{CHO}_{(\text {ads })}+\mathrm{O}_{(s)} \rightarrow \mathrm{CH}_{3} \mathrm{COCH}_{3(a d s)}+\mathrm{H}_{2}+\mathrm{CO}_{2} \\
2 \mathrm{CH}_{3} \mathrm{COCH}_{3} \rightarrow\left(\mathrm{CH}_{3}\right)_{2} \mathrm{CO}(\mathrm{OH}) \mathrm{CH}_{2} \mathrm{COCH}_{3} \rightarrow\left(\mathrm{CH}_{3}\right)_{2} \mathrm{C}=\mathrm{CHC}(\mathrm{O}) \mathrm{CH}_{3}+\mathrm{H}_{2} \mathrm{O}
\end{gathered}
$$



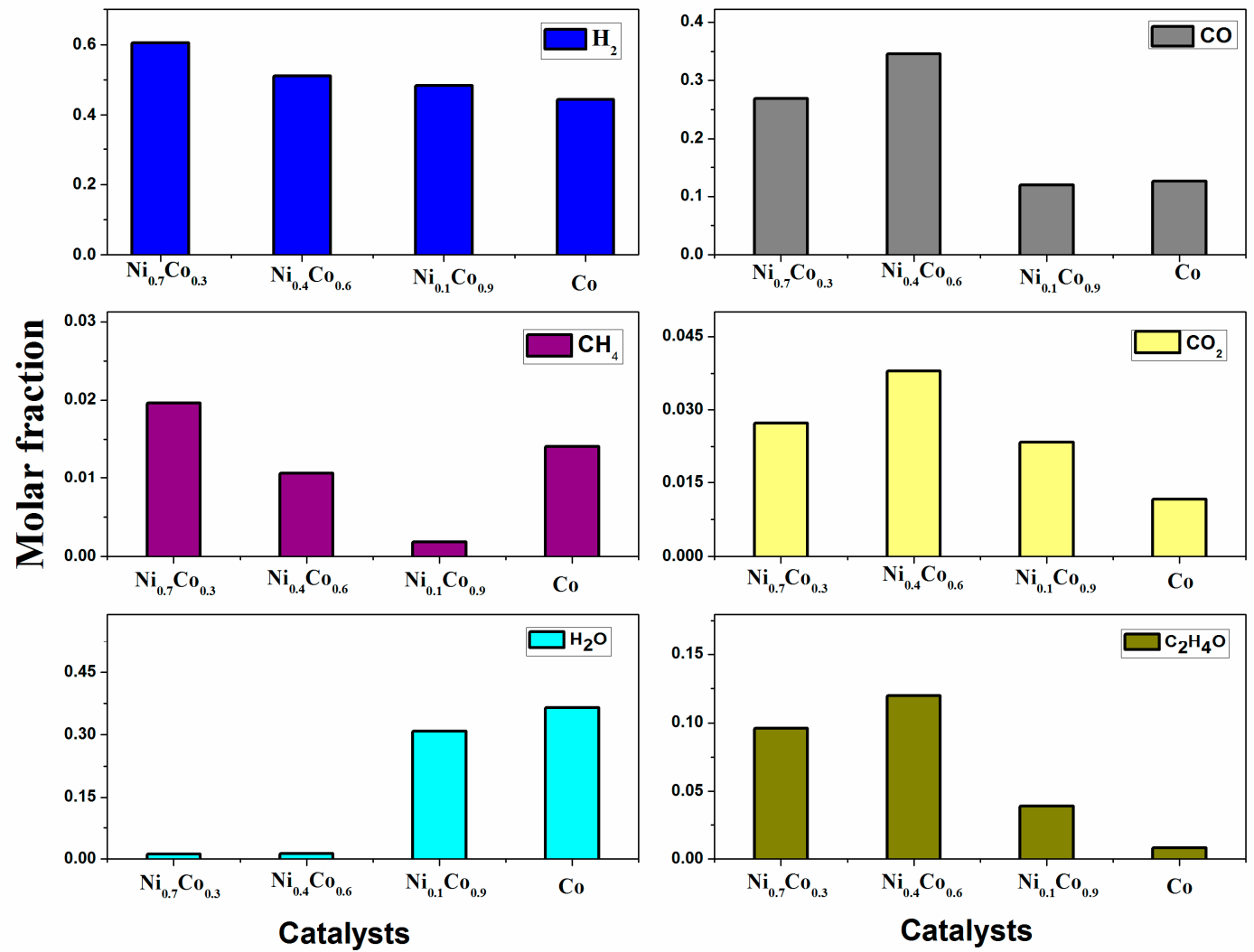

Figure 13. Product distribution in ethanol decomposition on $\mathrm{Ni}_{\mathrm{x}} \mathrm{Co}_{1-\mathrm{x}} / \mathrm{La}_{0.8} \mathrm{Ce}_{0.2}$ catalysts at $1 \mathrm{~h}$ of reaction at $973 \mathrm{~K}$.

Table 3. Carbon deposition on $\mathrm{Ni}_{\mathrm{x}} \mathrm{Co}_{1-\mathrm{x}} / \mathrm{La}_{0.8} \mathrm{Ce}_{0.2}$ catalysts evaluated by TGA.

\begin{tabular}{cccc}
\hline Catalyst & $\mathbf{m g}_{\text {coke }} / \mathbf{g}_{\text {cat }}$ & $\mathbf{T}_{\text {peak }} \mathbf{D T G}$ & $\mathbf{I}_{\mathbf{D}} / \mathbf{I}_{\mathbf{G}}$ \\
\hline $\mathrm{Co} / \mathrm{La}_{0.8} \mathrm{Ce}_{0.2}$ & 530.5 & 773 & 1.00 \\
$\mathrm{Ni}_{0.1} \mathrm{Co}_{0.9} / \mathrm{La}_{0.8} \mathrm{Ce}_{0.2}$ & 659.5 & 980 & 0.98 \\
$\mathrm{Ni}_{0.4} \mathrm{Co}_{0.6} / \mathrm{La}_{0.8} \mathrm{Ce}_{0.2}$ & 592.1 & 830 & 0.99 \\
$\mathrm{Ni}_{0.7} \mathrm{Co}_{0.3} / \mathrm{La}_{0.8} \mathrm{Ce}_{0.2}$ & 342.6 & 780 & 0.99 \\
\hline
\end{tabular}

The low amounts of $\mathrm{CH}_{4}$ detected in experiments carried out with the $\mathrm{Ni}_{0.1} \mathrm{Co}_{0.9}$ catalyst indicate that methane decomposition could be occurring, thereby promoting catalyst deactivation (Equation (3)). Furthermore, the lower amount of $\mathrm{CO}$ observed on $\mathrm{Ni}_{0.1} \mathrm{Co}_{0.9}$ and $\mathrm{Co}$ may be due to the participation of the Boudouard reaction (Equation (2)), which also leads to catalyst deactivation by carbon deposition. This observation agrees with obtained results by TGA and Raman experiments (see Section 3.2).

On the $\mathrm{Ni}_{0.1} \mathrm{Co}_{0.9}$ and Co catalysts, a high presence of $\mathrm{H}_{2} \mathrm{O}$ was found. $\mathrm{H}_{2} \mathrm{O}$ can originate from the ethanol dehydration reaction (Equation (12)), one of the most reported reactions involved in the catalyst deactivation in this type of process [2], which is favored over acid catalysts. Ethylene thus formed can polymerize to coke. According to the acidity measurements (Table 1), the catalysts with the most acidic sites were $\mathrm{Ni}_{0.4} \mathrm{Co}_{0.6} / \mathrm{La0}_{0.8} \mathrm{Ce}_{0.2}>\mathrm{Co} / \mathrm{LaO}_{0.8} \mathrm{Ce}_{0.2}>\mathrm{Ni}_{0.1} \mathrm{Co}_{0.9} / \mathrm{La0}_{0.8} \mathrm{Ce}_{0.2}$ and these were also the ones with the highest carbon content (Table 3) after $13 \mathrm{~h}$ of reaction in the order $\mathrm{Ni}_{0.1} \mathrm{Co}_{0.9} / \mathrm{LaO}_{0.8} \mathrm{Ce}_{0.2}>$ $\mathrm{Ni}_{0.4} \mathrm{Co}_{0.6} / \mathrm{LaO}_{0.8} \mathrm{Ce}_{0.2}>\mathrm{Co} / \mathrm{LaO}_{0.8} \mathrm{Ce}_{0.2} \mathrm{Ni}$. Although $\mathrm{H}_{2} \mathrm{O}$ can also form from the methanation reaction (Equations (8) and (9)), no high $\mathrm{CH}_{4}$ content in evolved gases was found to justify this route.

$$
\mathrm{CH}_{3} \mathrm{CH}_{2} \mathrm{OH} \rightarrow \mathrm{C}_{2} \mathrm{H}_{4}+\mathrm{H}_{2} \mathrm{O}
$$

The $\mathrm{Ni}_{0.7} \mathrm{Co}_{0.3} / \mathrm{La0}_{0.8} \mathrm{Ce}_{0.2}$ catalyst displayed the higher ethanol conversion, selectivity to $\mathrm{H}_{2}$, and initial rate. Additionally, it was the catalyst with lower carbon deposition. These results can be related 
to its greater metal dispersion also associated with the highest specific surface area and much lower acidity compared to other catalysts. The amounts of metal used gave rise to an important metallic interaction, thus affecting both structural and electronic properties of the catalyst. In addition, the preparation method used led to metal nanoparticles being partially embedded in the oxide support, which displayed a lower tendency toward agglomeration and to coke deposition as mentioned in other studies [46-48]. Although a high carbon accumulation was observed on the catalysts, the stability only decreased slightly. This result may be due both to the formation of filamentous carbon on the catalysts, which does not always lead to catalyst deactivation [4], and to carbon gasification induced by metal-support interaction.

\subsection{Characterization of Spent Catalysts}

Thermogravimetric analyses of spent catalysts were carried out to calculate the amount of carbonaceous residues formed after ethanol decomposition by measuring the weight loss. TGA-DTG of the catalyst used containing only Co, presented in Figure 14, shows that the catalyst exhibited a peak at $770 \mathrm{~K}$, corresponding to the combustion of amorphous coke [22]. Meanwhile, Ni-containing catalysts showed loss mass at higher temperatures around $800 \mathrm{~K}$, which can be due to the combustion of filamentous coke with different graphitization degrees associated with nickel particles [22]. It is noteworthy that the $\mathrm{Ni}_{0.1} \mathrm{Co}_{0.9} / \mathrm{La}_{0.8} \mathrm{Ce}_{0.2}$ catalyst displayed a wide peak shifted at a higher temperature centered at $980 \mathrm{~K}$, which can be attributed to the presence of highly ordered coke. Increasing Ni content decreased the removal temperature of carbon deposits due to its lower ordering degree obtained by particle size decreasing (Table 1). The carbon depositions for spent samples quantified by TGA are shown in Table 3 . The $\mathrm{Ni}_{0.7} \mathrm{Co}_{0.3}$ catalyst with the smallest particle size (Table 1) was the most stable catalyst, since it showed the lowest amount of carbon deposits after $13 \mathrm{~h}$ of reaction, which is in agreement with previous studies [2,5,49].

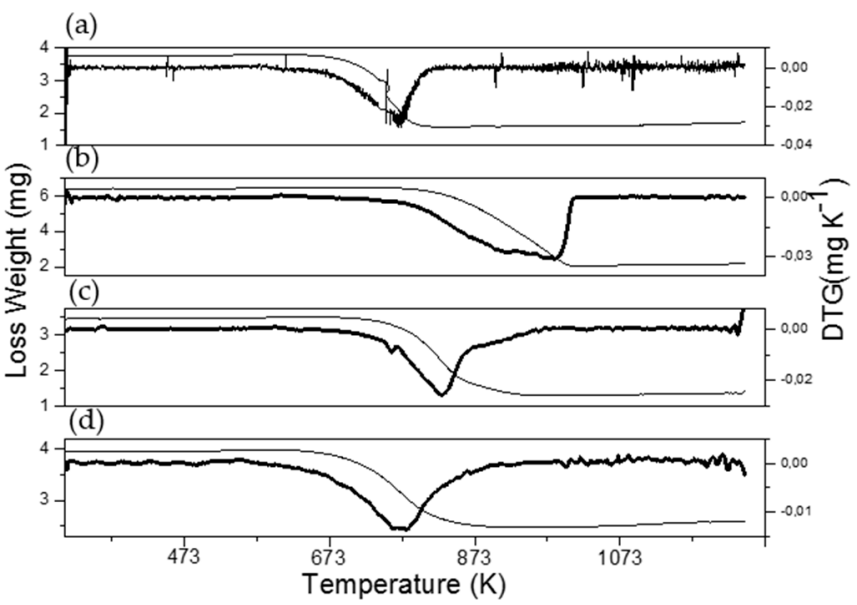

Figure 14. TGA-DTG of supported $\mathrm{Ni}_{1-\mathrm{x}} \mathrm{Co}_{x} / \mathrm{La}_{0.8} \mathrm{Ce}_{0.2}$ catalysts after the ethanol decomposition reaction: (a) $\mathrm{Co}$, (b) $\mathrm{Ni}_{0.1} \mathrm{Co}_{0.9}$, (c) $\mathrm{Ni}_{0.4} \mathrm{Co}_{0.6}$, and (d) $\mathrm{Ni}_{0.7} \mathrm{Co}_{0.3}$.

On the other hand, the presence and nature of carbon deposits on the catalyst surface were evaluated by Raman spectroscopy. The results are shown in Figure 15 . The bands at 1340 and $1580 \mathrm{~cm}^{-1}$ are labelled as D and G bands and their presence is evident in all solids. The $\mathrm{G}$ mode is attributed to the graphite structure, but it has also been associated in a general way with stretching vibration of $C=C$ bond in chains or in aromatic rings, whereas the $\mathrm{D}$ mode is the breathing mode of $\mathrm{C}=\mathrm{C}$ bonds only in rings [50,51]. This band is associated with the Raman mode of disordered defective carbon structures. Therefore, the heterogeneity of the carbon species can be related to the presence of both signals, $G$ and D. The intensity ratio of the D and G Raman bands (ID/IG) gives information on the type of coke [50] prevailing during reaction. For $\mathrm{Ni}_{0,1} \mathrm{Co}_{0,9} / \mathrm{La}_{0,8} \mathrm{Ce}_{0,2}$, a lower value was obtained, which agrees with 
the TGA results where a higher temperature was necessary to remove carbon deposits, as is shown in Figure 12 and Table 3.

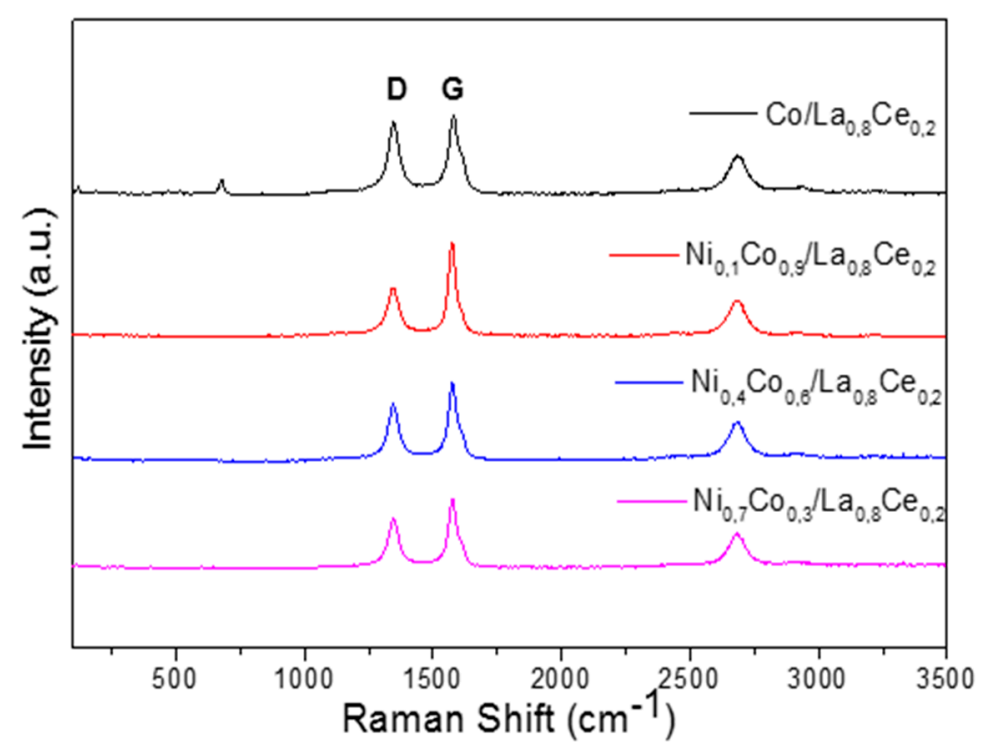

Figure 15. Raman spectra supported $\mathrm{Ni}_{\mathrm{x}} \mathrm{Co}_{1-\mathrm{x}} / \mathrm{La}_{0.8} \mathrm{Ce}_{0.2}$ catalysts.

\section{Conclusions}

Co-Ni bimetallic catalysts supported on La-Ce oxides were prepared by reducing $\mathrm{La}_{0.8} \mathrm{Ce}_{0.2} \mathrm{Ni}_{1-\mathrm{x}} \mathrm{Co}_{\mathrm{x}} \mathrm{O}_{3}$ perovskite precursors. The preparation method resulted in very small particle sizes that diminished with nickel content increase in the order $\mathrm{Ni}_{0.7} \mathrm{Co}_{0.3} / \mathrm{LaO}_{0.8} \mathrm{Ce}_{0.2} \leq$ $\mathrm{Ni}_{0.4} \mathrm{Co}_{0.6} / \mathrm{LaO}_{0.8} \mathrm{Ce}_{0.2}<\mathrm{Ni}_{0.1} \mathrm{Co}_{0.9} / \mathrm{LaO}_{0.8} \mathrm{Ce}_{0.2}<\mathrm{Co} / \mathrm{La0} 0.8 \mathrm{Ce}_{0.2}$ according to $\mathrm{H}_{2}$ chemisorption and TEM measurements. The $\mathrm{Ni}_{0.7} \mathrm{Co}_{0.3} / \mathrm{LaO}_{0.8} \mathrm{Ce}_{0.2}$ catalyst exhibited the higher ethanol conversion $(98.4 \%)$ and selectivity to $\mathrm{H}_{2}(75 \%)$ as well as the lower carbon deposit formation during the ethanol decomposition reaction as determined by TGA measurements. These observations were attributed to its smaller size particle, higher specific surface area, and much lower acidity compared to other catalysts. Despite the presence of coke, all catalysts were stable for $13 \mathrm{~h}$ of time on stream, which can be related to the strong metal-support interaction obtained due to the use of perovskites as precursors for the catalysts. This interaction can increase carbon gasification and decrease metal sintering as reported previously. Several side reactions are involved in $\mathrm{H}_{2}$ production by ethanol decomposition that can favor catalyst deactivation. According to product distribution, the side reactions responsible for the formation of carbon deposits were mainly methane decomposition, Boudouard reaction, and ethanol dehydration. In addition, acetate species could have blocked the active sites as observed in DRIFTS experiments, contributing also to the deactivation of the catalysts. Finally, the preparation method used in this study led to bimetallic Ni-Co catalysts supported on $\mathrm{La}_{2} \mathrm{O}_{3}-\mathrm{CeO}_{2}$ with small particle sizes, as well as being active and stable for ethanol decomposition for $\mathrm{H}_{2}$ production.

Author Contributions: H.R.V. contributed to validation, formal analysis, software, data curation, and investigation; M.H.B. contributed to formal analysis, conceptualization, methodology, software, investigation, supervision, data curation, and writing-review and editing; J.J.M. contributed to resources, conceptualization, supervision, project administration, and funding acquisition; H.A.R. contributed to resources, supervision, project administration, and funding acquisition; J.P. contributed to supervision and funding acquisition; F.B.P. contributed to methodology, software, and validation; L.P.d.C. contributed to methodology and software; D.G.-V. contributed to formal analysis and methodology; P.O.-V. contributed to conceptualization, supervision, data curation, writing-original draft preparation, and writing-review and editing. All authors have read and agreed to the published version of the manuscript.

Funding: This research was funded by FAPERJ, CNPq, CAPES, and VIE-UPTC, SGI 2446. 
Acknowledgments: L.P.C. acknowledges CNPQ process 311461/2017-4 and LME/LNNano/CNPEM for technical support during electron microscopy work.

Conflicts of Interest: The authors declare no conflict of interest

\section{References}

1. Ishizaki, H.; Hasumi, K. Ethanol Production from Biomass; Elsevier: Ámsterdam, The Netherlands, 2013; ISBN 9780124046092.

2. Mattos, L.V.; Jacobs, G.; Davis, B.H.; Noronha, F.B. Production of hydrogen from ethanol: Review of reaction mechanism and catalyst deactivation. Chem. Rev. 2012, 112, 4094-4123. [CrossRef]

3. De Lima, S.M.; da Silva, A.M.; da Costa, L.O.O.; Graham, U.M.; Jacobs, G.; Davis, B.H.; Mattos, L.V.; Noronha, F.B. Study of catalyst deactivation and reaction mechanism of steam reforming, partial oxidation, and oxidative steam reforming of ethanol over $\mathrm{Co} / \mathrm{CeO}_{2}$ catalyst. J. Catal. 2009, 268, 268-281. [CrossRef]

4. Campos, C.H.; Pecchi, G.; Fierro, J.L.G.; Osorio-Vargas, P. Enhanced bimetallic Rh-Ni supported catalysts on alumina doped with mixed lanthanum-cerium oxides for ethanol steam reforming. Mol. Catal. 2019, 469, 87-97. [CrossRef]

5. Rostrup-Nielsen, J.R. Sulfur-passivated nickel catalysts for carbon-free steam reforming of methane. J. Catal. 1984, 85, 31-43. [CrossRef]

6. He, S.; An, Z.; Wei, M.; Evans, D.G.; Duan, X. Layered double hydroxide-based catalysts: Nanostructure design and catalytic performance. Chem. Commun. 2013, 49, 5912-5920. [CrossRef] [PubMed]

7. Manukyan, K.V.; Cross, A.J.; Yeghishyan, A.V.; Rouvimov, S.; Miller, J.J.; Mukasyan, A.S.; Wolf, E.E. Highly stable $\mathrm{Ni}-\mathrm{Al} 2 \mathrm{O} 3$ catalyst prepared from a $\mathrm{Ni}$-Al layered double hydroxide for ethanol decomposition toward hydrogen. Appl. Catal. A Gen. 2015, 508, 37-44. [CrossRef]

8. Ashok, A.; Kumar, A.; Ponraj, J.; Mansour, S.A.; Tarlochan, F. Effect of Ni incorporation in cobalt oxide lattice on carbon formation during ethanol decomposition reaction. Appl. Catal. B Environ. 2019, 254, 300-311. [CrossRef]

9. Gallego, J.; Sierra, G.; Mondragon, F.; Barrault, J.; Batiot-Dupeyrat, C. Synthesis of MWCNTs and hydrogen from ethanol catalytic decomposition over a Ni/La $\mathrm{O}_{3}$ catalyst produced by the reduction of $\mathrm{LaNiO}_{3}$. Appl. Catal. A Gen. 2011, 397, 73-81. [CrossRef]

10. Morales, R.; Campos, C.H.; Fierro, J.L.G.; Fraga, M.A.; Pecchi, G. Stable reduced Ni catalysts for xylose hydrogenation in aqueous medium. Catal. Today 2018, 310, 59-67. [CrossRef]

11. Kumar, A.; Miller, J.T.; Mukasyan, A.S.; Wolf, E.E. In situ XAS and FTIR studies of a multi-component $\mathrm{Ni} / \mathrm{Fe} / \mathrm{Cu}$ catalyst for hydrogen production from ethanol. Appl. Catal. A Gen. 2013, 467, 593-603. [CrossRef]

12. De Lima, S.M.; Silva, A.M.; Graham, U.M.; Jacobs, G.; Davis, B.H.; Mattos, L.V.; Noronha, F.B. Ethanol decomposition and steam reforming of ethanol over $\mathrm{CeZrO}_{2}$ and $\mathrm{Pt} / \mathrm{CeZrO}$ catalyst: Reaction mechanism and deactivation. Appl. Catal. A Gen. 2009, 352,95-113. [CrossRef]

13. Dancini-Pontes, I.; Fernandes-Machado, N.R.C.; De Souza, M.; Pontes, R.M. Insights into ethanol decomposition over Pt: A DFT energy decomposition analysis for the reaction mechanism leading to $\mathrm{C}_{2} \mathrm{H}_{6}$ and $\mathrm{CH}_{4}$. Appl. Catal. A Gen. 2015, 491, 86-93. [CrossRef]

14. De Souza, G.; Balzaretti, N.M.; Marcílio, N.R.; Perez-Lopez, O.W. Decomposition of ethanol over Ni-Al catalysts: Effect of copper addition. Procedia Eng. 2012, 42, 335-345. [CrossRef]

15. Diao, J.; Wang, H.; Li, W.; Wang, G.; Ren, Z.; Bai, J. Effect of C-supported Co catalyst on the ethanol decomposition to produce hydrogen and multi-walled carbon nanotubes. Phys. E Low-Dimensional Syst. Nanostruct. 2010, 42, 2280-2284. [CrossRef]

16. Chen, R.; Xie, Y.; Zhou, Y.; Wang, J.; Wang, H. Production of hydrogen-rich gas and multi-walled carbon nanotubes from ethanol decomposition over molybdenum modified $\mathrm{Ni} / \mathrm{MgO}$ catalysts. J. Energy Chem. 2014, 23, 244-250. [CrossRef]

17. Wang, G.; Wang, H.; Tang, Z.; Li, W.; Bai, J. Simultaneous production of hydrogen and multi-walled carbon nanotubes by ethanol decomposition over $\mathrm{Ni} / \mathrm{Al}_{2} \mathrm{O}_{3}$ catalysts. Appl. Catal. B Environ. 2009, 88, 142-151. [CrossRef]

18. Li, W.; Wang, H.; Ren, Z.; Wang, G.; Bai, J. Co-production of hydrogen and multi-wall carbon nanotubes from ethanol decomposition over $\mathrm{Fe} / \mathrm{Al}_{2} \mathrm{O}_{3}$ catalysts. Appl. Catal. B Environ. 2008, 84, 433-439. [CrossRef] 
19. Mezalira, D.Z.; Probst, L.D.; Pronier, S.; Batonneau, Y.; Batiot-Dupeyrat, C. Decomposition of ethanol over $\mathrm{Ni} / \mathrm{Al}_{2} \mathrm{O}_{3}$ catalysts to produce hydrogen and carbon nanostructured materials. J. Mol. Catal. A Chem. 2011, 340, 15-23. [CrossRef]

20. Laosiripojana, N.; Sutthisripok, W.; Assabumrungrat, S. Reactivity of high surface area $\mathrm{CeO}_{2}$ synthesized by surfactant-assisted method to ethanol decomposition with and without steam. Chem. Eng. J. 2007, 127, 31-38. [CrossRef]

21. Manukyan, K.V.; Yeghishyan, A.V.; Danghyan, V.; Rouvimov, S.; Mukasyan, A.S.; Wolf, E.E. Structural transformations of highly porous nickel catalysts during ethanol conversion towards hydrogen. Int. J. Hydrogen Energy 2018, 43, 13225-13236. [CrossRef]

22. Osorio-Vargas, P.; Flores-González, N.A.; Navarro, R.M.; Fierro, J.L.G.; Campos, C.H.; Reyes, P. Improved stability of $\mathrm{Ni} / \mathrm{Al}_{2} \mathrm{O}_{3}$ catalysts by effect of promoters $\left(\mathrm{La}_{2} \mathrm{O}_{3}, \mathrm{CeO}_{2}\right)$ for ethanol steam-reforming reaction. Catal. Today 2015, 259, 27-38. [CrossRef]

23. Pechini, M.P. Method of Pre Parng Lead and Alkalne Earth Titanates and Nobates and Coat. U.S. Patent 3,330,697, 11 July 1967.

24. Marinho, A.L.A.; Rabelo-Neto, R.C.; Noronha, F.B.; Mattos, L.V. Steam reforming of ethanol over Ni-based catalysts obtained from $\mathrm{LaNiO}_{3}$ and $\mathrm{LaNiO}_{3} / \mathrm{CeSiO}_{2}$ perovskite-type oxides for the production of hydrogen. Appl. Catal. A Gen. 2016, 520, 53-64. [CrossRef]

25. Franchini, C.A.; Aranzaez, W.; Duarte de Farias, A.M.; Pecchi, G.; Fraga, M.A. Ce-substituted $\mathrm{LaNiO}_{3}$ mixed oxides as catalyst precursors for glycerol steam reforming. Appl. Catal. B Environ. 2014, 147, 193-202. [CrossRef]

26. Yang, E.H.; Kim, N.Y.; Noh, Y.S.; Lim, S.S.; Jung, J.S.; Lee, J.S.; Hong, G.H.; Moon, D.J. Steam $\mathrm{CO}_{2}$ reforming of methane over $\mathrm{La}_{1-\mathrm{x}} \mathrm{Ce}_{\mathrm{x}} \mathrm{NiO}_{3}$ perovskite catalysts. Int. J. Hydrogen Energy 2015, 40, 11831-11839. [CrossRef]

27. De Lima, S.M.; da Silva, A.M.; da Costa, L.O.O.; Assaf, J.M.; Mattos, L.V.; Sarkari, R.; Venugopal, A.; Noronha, F.B. Hydrogen production through oxidative steam reforming of ethanol over Ni-based catalysts derived from $\mathrm{La}_{1-x} \mathrm{Ce}_{x} \mathrm{NiO}_{3}$ perovskite-type oxides. Appl. Catal. B Environ. 2012, 121-122, 1-9. [CrossRef]

28. Ma, F.; Chu, W.; Huang, L.; Yu, X.; Wu, Y. Steam reforming of ethanol over Zn-Doped $\mathrm{LaCoO}_{3}$ perovskite nanocatalysts. Chin. J. Catal. 2011, 32, 970-977. [CrossRef]

29. Wang, Z.; Wang, C.; Chen, S.; Liu, Y. Co-Ni bimetal catalyst supported on perovskite-type oxide for steam reforming of ethanol to produce hydrogen. Int. J. Hydrogen Energy 2014, 39, 5644-5652. [CrossRef]

30. Sing, K.S.W.; Everett, D.H.; Haul, R.A.W.; Moscou, L.; Pierotti, R.A.; Rouquerol, J.; Siemieniewska, T. Reporting physisorption data for gas/solid systems with Special Reference to the Determination of Surface Area and Porosity (Recommendations 1984). Pure Appl. Chem. 1985, 57, 603-619. [CrossRef]

31. Tang, Z.; Cao, H.; Tao, Y.; Heeres, H.J.; Pescarmona, P.P. Transfer hydrogenation from glycerol over a $\mathrm{Ni}-\mathrm{Co} / \mathrm{CeO}_{2}$ catalyst: A highly efficient and sustainable route to produce lactic acid. Appl. Catal. B Environ. 2020, 263, 118273. [CrossRef]

32. Biesinger, M.C.; Payne, B.P.; Lau, L.W.M.; Gerson, A.; Smart, R.S.C. X-ray photoelectron spectroscopic chemical state Quantification of mixed nickel metal, oxide and hydroxide systems. Surf. Interface Anal. 2009, 41, 324-332. [CrossRef]

33. Grosvenor, A.P.; Biesinger, M.C.; Smart, R.S.C.; McIntyre, N.S. New interpretations of XPS spectra of nickel metal and oxides. Surf. Sci. 2006, 600, 1771-1779. [CrossRef]

34. Biesinger, M.C.; Payne, B.P.; Grosvenor, A.P.; Lau, L.W.M.; Gerson, A.R.; Smart, R.S.C. Resolving surface chemical states in XPS analysis of first row transition metals, oxides and hydroxides: $\mathrm{Cr}, \mathrm{Mn}, \mathrm{Fe}, \mathrm{Co}$ and $\mathrm{Ni}$. Appl. Surf. Sci. 2011, 257, 2717-2730. [CrossRef]

35. Chuang, T.J.; Brundle, C.R.; Rice, D.W. Interpretation of the x-ray photoemission spectra of cobalt oxides and cobalt oxide surfaces. Surf. Sci. 1976, 59, 413-429. [CrossRef]

36. Huck-Iriart, C.; Soler, L.; Casanovas, A.; Marini, C.; Prat, J.; Llorca, J.; Escudero, C. Unraveling the Chemical State of Cobalt in Co-Based Catalysts during Ethanol Steam Reforming: An in Situ Study by Near Ambient Pressure XPS and XANES. ACS Catal. 2018, 8, 9625-9636. [CrossRef]

37. Zhai, Y.; Chu, M.; Shang, N.; Wang, C.; Wang, H.; Gao, Y. Bimetal Co ${ }_{8} \mathrm{Ni}_{2}$ catalyst supported on chitin-derived N-containing carbon for upgrade of biofuels. Appl. Surf. Sci. 2019, 144681. [CrossRef]

38. Maslakov, K.I.; Teterin, Y.A.; Popel, A.J.; Teterin, A.Y.; Ivanov, K.E.; Kalmykov, S.N.; Petrov, V.G.; Petrov, P.K.; Farnan, I. XPS study of ion irradiated and unirradiated $\mathrm{CeO}_{2}$ bulk and thin film samples. Appl. Surf. Sci. 2018, 448, 154-162. [CrossRef] 
39. Bêche, E.; Charvin, P.; Perarnau, D.; Abanades, S.; Flamant, G. Ce 3d XPS investigation of cerium oxides and mixed cerium oxide $\left(\mathrm{Ce}_{\mathrm{x}} \mathrm{Ti}_{\mathrm{y}} \mathrm{O}_{\mathrm{z}}\right)$. Surf. Interface Anal. 2008, 40, 264-267. [CrossRef]

40. Paparazzo, E. XPS studies of damage induced by X-ray irradiation on $\mathrm{CeO}_{2}$ surfaces. Surf. Sci. 1990, 234, 1-6. [CrossRef]

41. Fleisch, T.H.; Hicks, R.F.; Bell, A.T. An XPS study of metal-support interactions on $\mathrm{Pd} \mathrm{SiO}_{2}$ and $\mathrm{Pd}_{\mathrm{La}} \mathrm{O}_{3}$. J. Catal. 1984, 87, 398-413. [CrossRef]

42. Araujo, J.C.S.; Zanchet, D.; Rinaldi, R.; Schuchardt, U.; Hori, C.E.; Fierro, J.L.G.; Bueno, J.M.C. The effects of $\mathrm{La}_{2} \mathrm{O}_{3}$ on the structural properties of $\mathrm{La}_{2} \mathrm{O}_{3}-\mathrm{Al}_{2} \mathrm{O}_{3}$ prepared by the sol-gel method and on the catalytic performance of $\mathrm{Pt} / \mathrm{La}_{2} \mathrm{O}_{3}-\mathrm{Al}_{2} \mathrm{O}_{3}$ towards steam reforming and partial oxidation of methane. Appl. Catal. $B$ Environ. 2008, 84, 552-562. [CrossRef]

43. De Lima, S.M.; da Cruz, I.O.; Jacobs, G.; Davis, B.H.; Mattos, L.V.; Noronha, F.B. Steam reforming, partial oxidation, and oxidative steam reforming of ethanol over $\mathrm{Pt} / \mathrm{CeZrO}$ catalyst. J. Catal. 2008, 257, 356-368. [CrossRef]

44. Mattos, L.V.; Noronha, F.B. Hydrogen production for fuel cell applications by ethanol partial oxidation on $\mathrm{Pt} / \mathrm{CeO}_{2}$ catalysts: The effect of the reaction conditions and reaction mechanism. J. Catal. 2005, 233, 453-463. [CrossRef]

45. Erdőhelyi, A.; Raskó, J.; Kecskés, T.; Tóth, M.; Dömök, M.; Baán, K. Hydrogen formation in ethanol reforming on supported noble metal catalysts. Catal. Today 2006, 116, 367-376. [CrossRef]

46. Wang, H.; Dong, X.; Zhao, T.; Yu, H.; Li, M. Dry reforming of methane over bimetallic Ni-Co catalyst prepared from $\mathrm{La}\left(\mathrm{Co}_{\mathbf{x}} \mathrm{Ni}_{1-\mathrm{x}}\right)_{0.5} \mathrm{Fe}_{0.5} \mathrm{O}_{3}$ perovskite precursor: Catalytic activity and coking resistance. Appl. Catal. B Environ. 2019, 245, 302-313. [CrossRef]

47. Neagu, D.; Oh, T.S.; Miller, D.N.; Ménard, H.; Bukhari, S.M.; Gamble, S.R.; Gorte, R.J.; Vohs, J.M.; Irvine, J.T.S. Nano-socketed nickel particles with enhanced coking resistance grown in situ by redox exsolution. Nat. Commun. 2015, 6, 8120. [CrossRef] [PubMed]

48. Wei, T.; Jia, L.; Zheng, H.; Chi, B.; Pu, J.; Li, J. LaMnO 3 -based perovskite with in-situ exsolved Ni nanoparticles: A highly active, performance stable and coking resistant catalyst for $\mathrm{CO}_{2}$ dry reforming of $\mathrm{CH}_{4}$. Appl. Catal. A Gen. 2018, 564, 199-207. [CrossRef]

49. Campos, C.H.; Osorio-Vargas, P.; Flores-González, N.; Fierro, J.L.G.; Reyes, P. Effect of Ni Loading on Lanthanide (La and Ce) Promoted $\gamma-\mathrm{Al}_{2} \mathrm{O}_{3}$ Catalysts Applied to Ethanol Steam Reforming. Catal. Lett. 2016, 146, 433-441. [CrossRef]

50. Iglesias-Juez, A.; Beale, A.M.; Maaijen, K.; Weng, T.C.; Glatzel, P.; Weckhuysen, B.M. A combined in situ time-resolved UV-Vis, Raman and high-energy resolution X-ray absorption spectroscopy study on the deactivation behavior of $\mathrm{Pt}$ and $\mathrm{PtSn}$ propane dehydrogenation catalysts under industrial reaction conditions. J. Catal. 2010, 276, 268-279. [CrossRef]

51. Mutz, B.; Sprenger, P.; Wang, W.; Wang, D.; Kleist, W.; Grunwaldt, J.D. Operando Raman spectroscopy on $\mathrm{CO}_{2}$ methanation over alumina-supported $\mathrm{Ni}, \mathrm{Ni}_{3} \mathrm{Fe}$ and $\mathrm{NiRh}_{0.1}$ catalysts: Role of carbon formation as possible deactivation pathway. Appl. Catal. A Gen. 2018, 556, 160-171. [CrossRef]

(C) 2020 by the authors. Licensee MDPI, Basel, Switzerland. This article is an open access article distributed under the terms and conditions of the Creative Commons Attribution (CC BY) license (http://creativecommons.org/licenses/by/4.0/). 